DEPARTMENT OF COMMERCE BUREAU OF STANDARDS

George K. Burgess, Director

TECHNOLOGIC PAPERS OF THE BUREAU OF STANDARDS, No. 336

[Part of Vol. 21]

\title{
COMPARATIVE TESTS \\ OF SIX-INCH CAST-IRON PIPES OF AMERICAN AND FRENCH MANUFACTURE
}

BY

S. N. PETRENKO, Associate Mechanical Engineer

Bureau of Standards

March 1, 1927

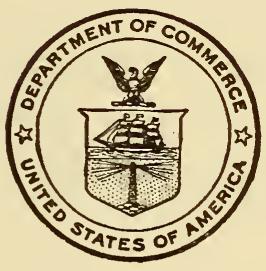

PRICE 15 CENTS

\$1.25 PER VOLUME ON SUBSCRIPTION

Sold only by the Superintendent of Documents, Government Printing Office Washington, D. C.

UNITED STATES

GOVERNMENT PRINTING OFFICE

WASHINGTON

1927 



\title{
COMPARATIVE TESTS OF SIX-INCH CAST-IRON PIPES OF AMERICAN AND FRENCH MANUFACTURE
}

\author{
By S. N. Petrenko
}

AESTRACT

Comparative tests were made on 6-inch cast-iron pipe manufactured in France and on similar pipe manufactured in this country. The pipes were of "bell and spigot" type and were cast in sand molds.

The tests, which included hardness, transverse, ring, shear, impact, and hydrostatic tests, had shown that the strength of the French pipe lay within the range of variation of the American pipe. Its deflection in transverse test was much lower than that of American pipe. The French pipe was also characterized by greater hardness, low impact values, and a higher content of phosphorus (about 1.85 per cent) than in American pipe.

The compressive test of the rings cut from the pipe seemed to give results which are fairly representative of the properties of the pipe, and is suggested as a substitute for transverse test of arbitration bars or coupons.

\section{CONTENTS}

I. Introduction

II. Acknowledgments

III. Methods of manufacture of pipes..... 232

IV. Selection of samples_._.

1. Size of pipe

2. Inspection of pipe

3. Selection of pipe

V. Test specimens._.

VI. Testing procedure

1. Measurement of dimensions

(a) Inside diameter............ 234

(b) Thickness of wall

(c) Weight of 1 linear foot of pipe.......... 236

(d) Density _...

2. Hardness

3. Transverse tests.

4. Ring test

5. Shear test._.

6. Impact test...

7. Hydrostatic test

VII. The results of tests and discussion of the results_._._._._._. 237

1. Dimensional characteristics of pipes._._. 237

2. Chemical composition. - 238

3. Microstructure_-_-_-_- 238

4. Density

5. Hardness test. 
VII. The results of tests and discussion of the results-Continued.

6. Transverse test

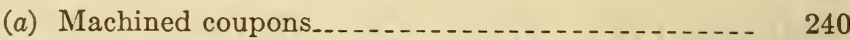

(b) Unmachined coupons_._._._. 241

(c) Transverse test of sections of pipe

7. Ring test........ 242

(a) Machined rings . .

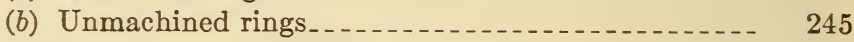

8. Shear test_...... 246

9. Impact test

10. Hydrostatic test_...... 247

VIII. Conclusions_._.

IX. Discussion of methods of testing cast-iron pipe._. 250

1. Brinell test.... 251

2. Flexure tests $\ldots \ldots 2$

3. Shear test....... 253

4. Impact test_... 253

5. Hydrostatic test

\section{INTRODUCTION}

During the last few years considerable quantities of cast-iron pipe were imported from France into this country. Up to the present time very little was known about the mechanical properties of this pipe, and the importation of the foreign product depended on price rather than on the properties of this material, as compared with the American product.

The Bureau of Standards was requested to make comparative tests on this pipe and on pipe which is manufactured in this country.

\section{ACKNOWLEDGMENTS}

The material for these tests was supplied and the specimens made by the Consolidated Gas Co., of New York.

The tests were planned and made by the engineering mechanics section in cooperation with other sections of this bureau. The chemical analyses were made in the division of chemistry, the microstructure was determined by the division of metallurgy, and the hydrostatic tests were made by the engineering instrument section.

Credit is due to H. L. Whittemore ${ }^{1}$ for many valuable suggestions made in working up the test data.

\section{METHODS OF MANUFACTURE OF PIPES}

The following information on the processes used in the manufacture of pipes was supplied by the Consolidated Gas Co., of New York. (See Table 1.) In this table, as well as in other parts of this paper, the letters $\mathrm{A}$ to $\mathrm{G}$ designate pipe of American manufacture and the letter H, pipe of French manufacture.

1 Chief, engineering mechanics section, United States Bureau of Standards. 
TABLE 1.-Method of manufacture of pipes

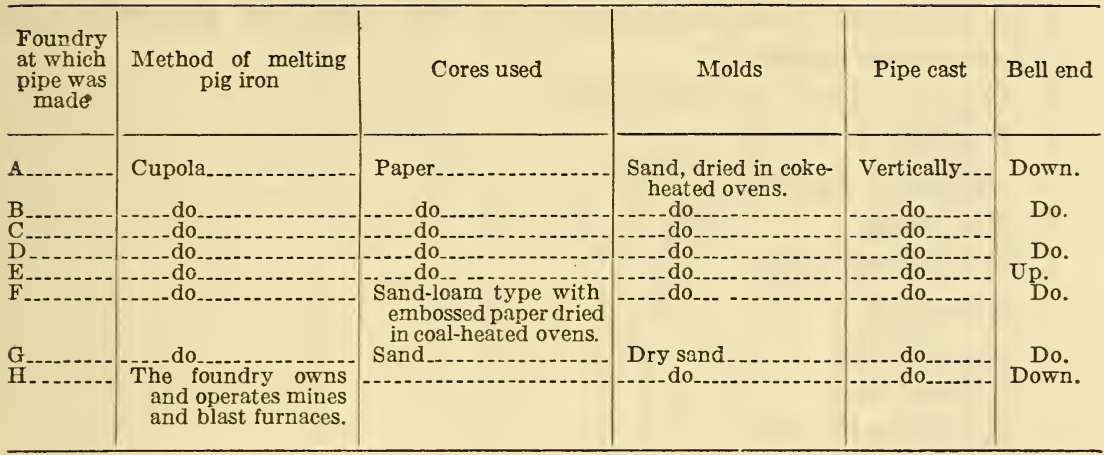

\section{SELECTION OF SAMPLES}

The samples of pipe were selected by the Frederic de P. Hone \& Co., inspecting engineers, for the Consolidated Gas Co., who described the procedure as follows:

\section{SIZE OF PIPE}

All test pieces were cut from "bell and spigot" pipe, 6 inches inside diameter, approximately 12 feet in length, and conforming to the dimensions specified by the American Gas Association. It was decided to select pipe of the above diameter as this size is in general use for gas mains and is readily obtainable from the foundries.

\section{INSPECTION OF PIPE}

Each length of pipe, except those from which the test pieces marked $\mathrm{H}$ were cut, was inspected at the foundry by inspectors employed by the Frederic de P. Hone \& Co. and tested in accordance with the American Gas Association specifications. The pipe from which the test pieces marked $\mathrm{H}$ were cut was given surface inspection only.

\section{SELECTION OF PIPE}

In selecting the lengths of pipe every effort was made to obtain lengths representing the usual foundry output and in no instance was the pipe specially cast for this purpose. The specimens of pipe for this investigation were selected from the following sources:

A. Selected from stock in foundry yards.

B. Selected from pipe in storage at the B gas company.

C. Selected from pipe in storage at the $\mathrm{C}$ gas company.

D. Selected from pipe in storage at the $\mathrm{D}$ gas company.

E. Selected from pipe in storage at the $\mathrm{E}$ gas company.

F. Selected from stock in foundry yards.

G. Selected from pipe in storage at the G gas company.

$H$. Selected from pipe in storage at the $\mathrm{H}$ gas company. 


\section{TEST SPECIMENS}

The following determininations of the physical properties of cast irons were made:

1. Measurements of dimensions.

2. Density.

3. Chemical analysis.

4. Hardness.

5. Transverse test.

6. Ring test.

7. Shear test.

8. Impact test.

9. Hydrostatic test.

10. Microstructure.

The dimensions of test specimens and their location in the pipe samples are shown in Figure 1.

The specimens were cut from the samples of pipe and machined under the constant supervision of an inspector from Frederic de P. Hone \& Co.

The density determinations were made on shear specimens and on the rings which were machined all over.

Hardness tests were made on shear specimens.

\section{TESTING PROCEDURE}

The following methods of measurement and testing were used:

\section{MEASUREMENTS OF DIMENSIONS}

(a) Inside Diameter. - The average inside diameter of pipe was measured by a steel scale to the nearest 0.01 inch.

(b) Thickness of Wall.- In view of the roughness of the pipe suriaces and considerable variation of the wall thickness in the same sample, the average thickness $t$ was determined by the formula:

where

$$
t=\frac{W}{\pi \times\left(d_{\mathrm{ins}}+t_{1}\right) \times l \times w}
$$

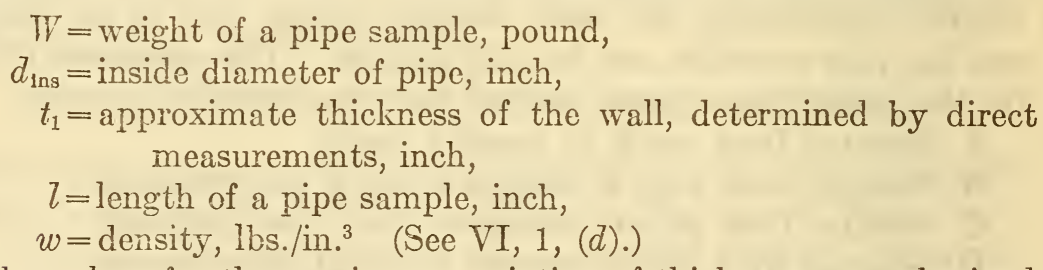

The values for the maximum variation of thickness were obtained by direct measurements. 


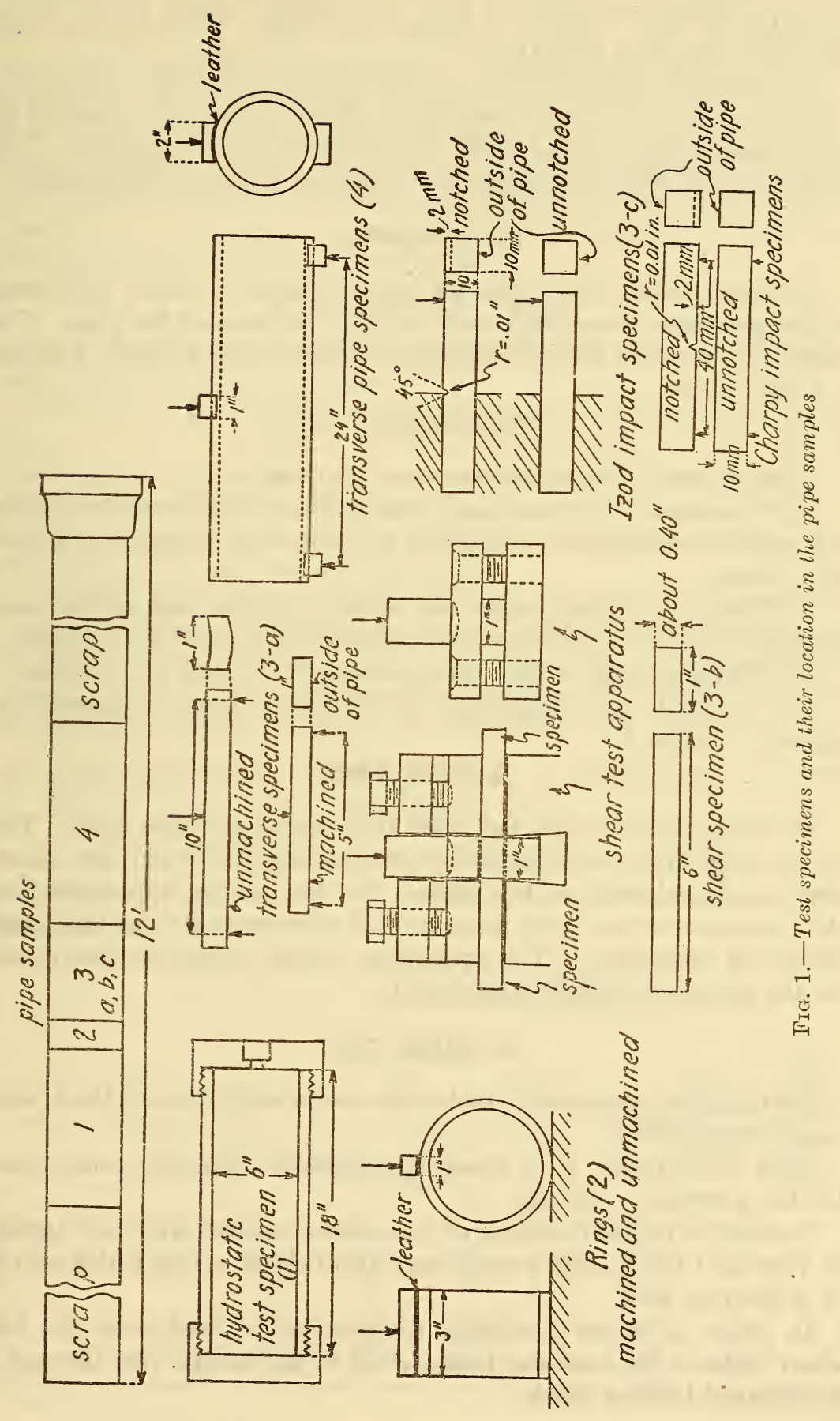


(c) Weight of 1 Linear Foot of Pipe.-This was determined by weighing 30 -inch lengths of pipe, an average being taken of six specimens for each foundry.

(d) Density.-The density was computed from the weight and volume of the machined specimens. The volume was obtained by the measurements of the linear dimensions of the specimens. The rings and the shear specimens were used for these determinations.

\section{HARDNESS}

Hardness tests were made on those surfaces of shear specimens which were near the outside and the inside surfaces of the pipe. The tests were made in a Brinell testing machine using a $10 \mathrm{~mm}$ ball and a $3,000 \mathrm{~kg}$ load.

\section{TRANSVERSE TESTS}

Three types of specimens were used in these tests:

(a) Specimens of rectangular cross-section, which were cut along the pipe and which were machined all over, were tested over a span of 5 inches.

(b) Specimens which were cut along the pipe and which were machined only on the edges were tested over a span of 10 inches.

(c) Whole sections of pipe were tested over a span of 24 inches.

The methods of supporting and loading these specimens are shown in Figure 1.

\section{RING TEST}

The specimens for this test were rings about 3 inches wide. Two of the rings from each material were machined all over; four others were machined only on the edges. In this and in transverse tests the specimens which were machined all over are called in this paper machined specimens. The specimens which were machined only on the edges are called unmachined.

\section{SHEAR TEST}

Rectangular specimens 1 inch wide and about 0.4 inch thick were used for this test.

They were tested in a shearing apparatus specially constructed for the purpose. (See fig. 1.)

In order to prevent bending of a specimen, its ends were held tightly in vises and the middle portion was also held in a vise which served as a shearing tool.

In order to insure a uniform distribution of load over the two shear surfaces the load was transmitted to the middle vise through a ball-shaped loading block. 


\section{IMPACT TEST}

Specimens were cut along the pipe and the blow applied on the side corresponding to the inner surface of pipe. Both notched and unnotched specimens were tested. The specimens were tested as cantilever beams, in an Izod machine of 120 foot-pounds capacity. It was realized that this machine could not give as accurate results as were desirable because of the large capacity of the Izod machine. After these tests were completed a Charpy type Amsler impact machine of 8 foot-pounds capacity was purchased, and another series of impact specimens were tested.

\section{HYDROSTATIC TEST}

The dimensions of the specimens which were used in the hydrostatic test are shown in Figure 1.

The internal hydrostatic pressure was applied by means of a force pump. It was increased until the specimen failed. The pressure was measured by a Bourdon tube gauge, the smallest division of which corresponded to a pressure of $10 \mathrm{lbs} . / \mathrm{in} .{ }^{2}$.

The gauge was calibrated both before and after the tests. The error did not exceed one scale division.

In testing the first four specimens of each group, the pressure was increased gradually at the rate of about $100 \mathrm{lbs}$./in. ${ }^{2}$ per second until failure occurred. In testing the last two specimens of each group, the pressure was applied in increments of $300 \mathrm{lbs}$./in. ${ }^{2}$. Each increment was maintained for one minute, or until failure occurred.

\section{THE RESULTS OF TESTS AND DISCUSSION OF THE RESULTS}

\section{DIMENSIONAL CHARACTERISTICS OF PIPES}

In Table 2 are given the average values for the dimensions of pipes and also their maximum variations.

TABLE 2.-Dimensional characteristics of pipes

[Values in this table are averages for at least six determinations]

\begin{tabular}{|c|c|c|c|c|c|c|c|c|}
\hline \multirow{2}{*}{ Cast iron } & \multirow{2}{*}{$\begin{array}{l}\text { Average } \\
\text { inside } \\
\text { diameter }\end{array}$} & \multirow{2}{*}{$\begin{array}{l}\text { Maxi- } \\
\text { mum } \\
\text { variation } \\
\text { of inside } \\
\text { diameter }\end{array}$} & \multicolumn{2}{|c|}{$\begin{array}{l}\text { Average thickness } \\
\text { of wall }\end{array}$} & \multirow{2}{*}{$\begin{array}{l}\text { Maxi- } \\
\text { mum } \\
\text { variation } \\
\text { of thick- } \\
\text { ness of } \\
\text { wall }\end{array}$} & \multirow{2}{*}{$\begin{array}{l}\text { Weight } \\
\text { per linear } \\
\text { foot }\end{array}$} & \multirow{2}{*}{$\begin{array}{l}\text { Maxi- } \\
\text { mum } \\
\text { variation } \\
\text { of weight } \\
\text { per linear } \\
\text { foot }\end{array}$} & \multirow{2}{*}{$\begin{array}{l}\text { Thick- } \\
\text { ness of } \\
\text { wall less } \\
\text { than } 0.35 \\
\text { inch was } \\
\text { found; } \\
\text { number } \\
\text { of speci- } \\
\text { mens }{ }^{1}\end{array}$} \\
\hline & & & $\begin{array}{l}\text { Deter- } \\
\text { mined by } \\
\text { density }\end{array}$ & $\begin{array}{l}\text { Deter- } \\
\text { mined by } \\
\text { actual } \\
\text { measure- } \\
\text { ments }\end{array}$ & & & & \\
\hline & $\begin{array}{l}\text { Inches } \\
6.08 \\
6.02 \\
6.10 \\
6.05\end{array}$ & $\begin{array}{l}\text { Inch } \\
0.05 \\
.06 \\
.08 \\
.07\end{array}$ & $\begin{array}{l}\text { Inch } \\
0.442 \\
.465 \\
.441 \\
.472\end{array}$ & $\begin{array}{r}\text { Inch } \\
0.432 \\
.446 \\
.429 \\
.457\end{array}$ & $\begin{array}{r}\text { Inch } \\
0.13 \\
.14 \\
.11 \\
.12\end{array}$ & $\begin{array}{r}L b s . / f t . \\
27.16 \\
28.36 \\
27.18 \\
28.98\end{array}$ & $\begin{array}{r}\text { Per cent } \\
4.1 \\
9.6 \\
6.7 \\
8.1\end{array}$ & \\
\hline & $\begin{array}{l}6.07 \\
6.10 \\
6.04 \\
6.02\end{array}$ & $\begin{array}{l}.10 \\
.07 \\
.13 \\
.10\end{array}$ & $\begin{array}{l}.443 \\
.414 \\
.430 \\
.454\end{array}$ & $\begin{array}{r}.423 \\
.413 \\
.419 \\
.439\end{array}$ & $\begin{array}{l}.14 \\
.15 \\
.16 \\
.12\end{array}$ & $\begin{array}{l}27.22 \\
25.42 \\
25.86 \\
27.24\end{array}$ & $\begin{array}{r}5.4 \\
4.5 \\
16.1 \\
11.6\end{array}$ & \\
\hline
\end{tabular}

1 Out of 12 specimens.

$25458^{\circ}-27-2$ 


\section{CHEMICAL COMPOSITION}

The results of chemical analysis are given in Table 3 .

TABLE 3.-Chemical analysis

\begin{tabular}{|c|c|c|c|c|c|c|c|}
\hline Cast iron & $\begin{array}{c}\text { Total } \\
\text { carbon }\end{array}$ & $\begin{array}{c}\text { Graphitic } \\
\text { carbon }\end{array}$ & $\begin{array}{l}\text { Com- } \\
\text { bined } \\
\text { carbon }\end{array}$ & $\underset{\text { nese }}{\text { Manga- }}$ & $\begin{array}{l}\text { Phos- } \\
\text { phorus }\end{array}$ & Sulphur & Silicon \\
\hline $\begin{array}{l}\mathrm{A} \\
\mathrm{B} \\
\mathrm{C} \\
\mathrm{D}\end{array}$ & $\begin{array}{r}\text { Per cent } \\
3.83 \\
3.77 \\
3.60 \\
3.59\end{array}$ & $\begin{array}{r}\text { Per cent } \\
3.16 \\
3.03 \\
2.92 \\
2.81\end{array}$ & $\begin{array}{r}\text { Per cent } \\
0.67 \\
.74 \\
.68 \\
.78\end{array}$ & $\begin{array}{r}\text { Per cent } \\
0.72 \\
.55 \\
.42 \\
.42\end{array}$ & $\begin{array}{c}\text { Percent } \\
0.40 \\
.475 \\
.82 \\
.78\end{array}$ & $\begin{array}{r}\text { Per cent } \\
0.072 \\
.085 \\
.052 \\
.068\end{array}$ & $\begin{array}{r}\text { Per cent } \\
1.51 \\
1.34 \\
1.76 \\
1.53\end{array}$ \\
\hline $\begin{array}{l}\mathrm{E} \\
\mathrm{F} \\
\mathrm{G} \\
\mathrm{H}\end{array}$ & $\begin{array}{l}\text { 3. } 54 \\
\text { 3. } 60 \\
\text { 3. } 70 \\
\text { 3. } 18\end{array}$ & $\begin{array}{l}2.84 \\
2.74 \\
2.90 \\
2.87\end{array}$ & $\begin{array}{l}.70 \\
.86 \\
.80 \\
.31\end{array}$ & $\begin{array}{l}.48 \\
.62 \\
.48 \\
.46\end{array}$ & $\begin{array}{l}.785 \\
.70 \\
.51 \\
1.85\end{array}$ & $\begin{array}{l}.072 \\
.092 \\
.120 \\
.078\end{array}$ & $\begin{array}{l}1.89 \\
1.68 \\
1.46 \\
2.66\end{array}$ \\
\hline
\end{tabular}

The pipe $\mathrm{H}$ had considerably higher phosphorus than any other pipe. It is customary to add phosphorus, as this increases the fluidity of the molten metal and the soundness of the castings, but it is not known if this was done for this French pipe. The combined carbon is much lower for the $\mathrm{H}$ pipe than for any of the others. This is undoubtedly due to the higher percentage of silicon in the $\mathrm{H}$ pipe. It is well known that cast iron having a high percentage of combined carbon is brittle. With a given total carbon, the combined carbon, and consequently the brittleness, can be decreased by increasing the amount of silicon.

\section{MICROSTRUCTURE}

Longitudinal sections of pipes, perpendicular to the wall, were etched lightly with 2 per cent nitric acid in alcohol and heat tinted.

The following micrographs (see fig. 2) are fairly representative of the average microstructure of each cast iron.

The dark background is the pearlitic matrix, the light-colored, sharply cutlined constituent is the iron-iron-phosphide eutectic, the long black plates are the graphite flakes.

There was no very pronounced difference in the size or arrangement of the graphite flakes in these cast irons.

There was a greater amount of the iron-iron-phosphide eutectic present in cast-iron $\mathrm{H}$ than in any other. This was confirmed by the high phosphorus content of these specimens shown by the chemical analysis.

The micrograph (fig. 3) shows that considerable amount of free ferrite is present in cast-iron $\mathrm{H}$. The presence of free ferrite tends to decrease brittleness which is caused by the high phosphorus content.

From the above micrographs it can be seen that specimens $\mathrm{H}_{4}$ and $\mathrm{H}_{5}$ contain a good deal of ferrite. Specimen $\mathrm{H}_{6}$, however, contains no ferrite and in this respect is similar to the lots of American manufacture. 
Technologic Papers of the Bureau of Standards, Vol. 21

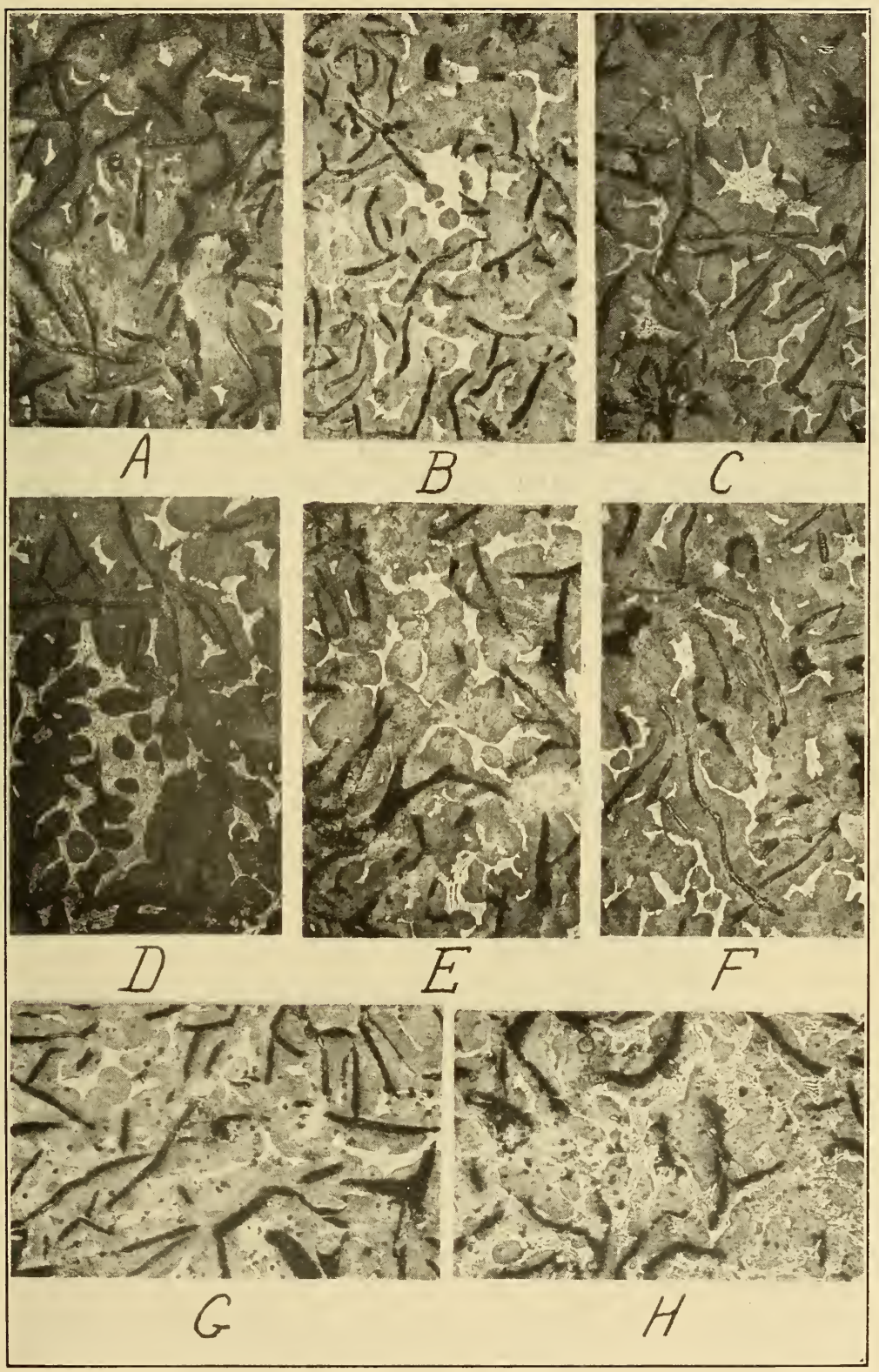

FIG. 2.-Microstructure of cast irons. $\quad \times 100$

The dark background is the pearlitic matrix; the light colored, sharply outlined constituent is the iron.iron phosphide eutectic; the long black plates are the graphite flakes 
Technologic Papers of the Bureau of Standards, Vol. 21

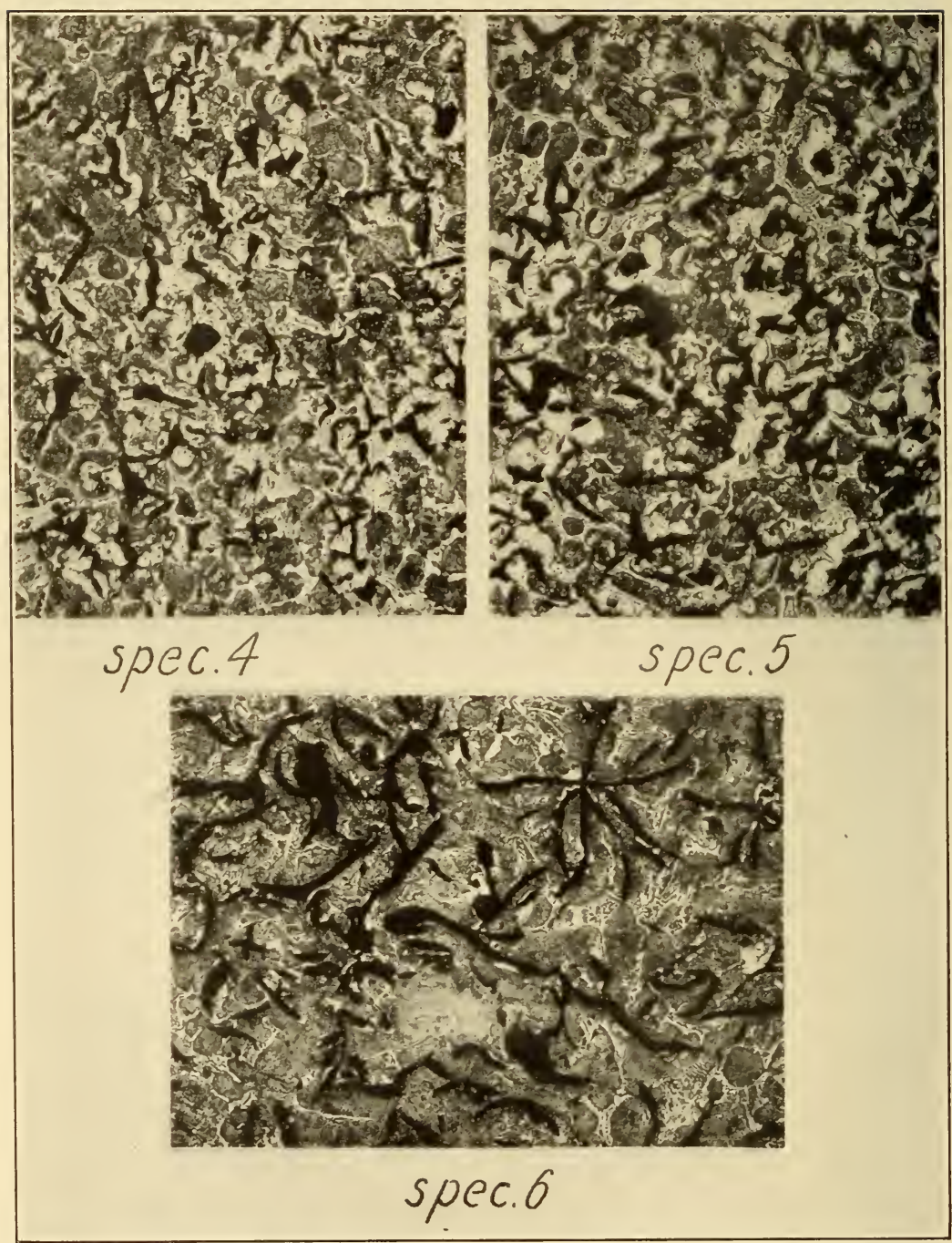

FIG. 3.-Microstructure of cast iron H. $\times 100$

The plain white areas are ferrite 
In some of the $\mathrm{H}$ pipes globules were found near the middle of the wall thickness. Some of these globules were about one-fourth inch in diameter. They had smooth surfaces and did not adhere firmly to the surrounding metal. They could be dislodged by blows of a hammer.

Probably these globules were formed by the flowing of molten iron into gas cavities under the increasing pressure as the mold filled. It is to be expected that the globules formed from iron which had not previously solidified would be high in phosphorus. This is shown by the chemical analysis of these globules:

$\mathrm{C}=2.54$ per cent,

$\mathrm{Mn}=0.36$ per cent,

$\mathrm{P}=3.60$ per cent,

$\mathrm{Si}=2.10$ per cent.

Apparently the presence of these globules did not appreciably affect the strength of the pipe.

\section{DENSITY}

The results of density determinations are found in Table 4.

TABLE 4.-Density determinations

\begin{tabular}{|c|c|c|c|c|c|c|c|}
\hline \multirow[b]{2}{*}{ Cast iron } & \multicolumn{2}{|c|}{$\begin{array}{l}\text { Average density } \\
\text { determined on- }\end{array}$} & \multirow[b]{2}{*}{$\begin{array}{l}\text { Average } \\
\text { density }\end{array}$} & \multirow[b]{2}{*}{ Cast iron } & \multicolumn{2}{|c|}{$\begin{array}{l}\text { Average density } \\
\text { determined on- }\end{array}$} & \multirow[b]{2}{*}{$\begin{array}{l}\text { Average } \\
\text { density }\end{array}$} \\
\hline & $\begin{array}{c}\text { Machined } \\
\text { rings }\end{array}$ & $\begin{array}{l}\text { Machined } \\
\text { shear } \\
\text { speci- } \\
\text { mens }{ }^{1}\end{array}$ & & & $\begin{array}{l}\text { Machined } \\
\text { rings } 1\end{array}$ & $\begin{array}{l}\text { Machined } \\
\text { shear } \\
\text { speci- } \\
\text { mens } 1\end{array}$ & \\
\hline D & $\begin{array}{r}\text { Lbs./in. }{ }^{3} \\
0.255 \\
.257 \\
.258 \\
.259\end{array}$ & $\begin{array}{r}\text { Lbs./in. }{ }^{3} \\
0.253 \\
.255 \\
.253 \\
.255\end{array}$ & $\begin{array}{c}\text { Lbs./in. }{ }^{3} \\
0.254 \\
.256 \\
.2555 \\
.257\end{array}$ & $\begin{array}{l}\mathrm{E} \\
\mathrm{F} \\
\mathrm{G} \\
\mathrm{H}\end{array}$ & $\begin{array}{r}\text { Lbs./in. }{ }^{3} \\
0.257 \\
.258 \\
.255 \\
.255\end{array}$ & $\begin{array}{r}\text { Lbs./in. }{ }^{3} \\
0.254 \\
.253 \\
.253 \\
.250\end{array}$ & $\begin{array}{r}\text { Lbs./in. }{ }^{3} \\
0.2555 \\
\quad .2555 \\
.2555 \\
.2525\end{array}$ \\
\hline
\end{tabular}

1 For the dimensions of these specimens see the results of the ring and the shear tests.

\section{HARDNESS TEST}

No appreciable difference was found between the Brinell numbers obtained on the two opposite surfaces of specimens corresponding to the outside and inside surfaces of the pipe, and, therefore, average values for the two surfaces are given in Table 5 .

TABLE 5.-Hardness

\begin{tabular}{|c|c|c|c|c|c|c|}
\hline 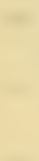 & Cast iron & $\begin{array}{c}\text { Average } \\
\text { Brinell } \\
\text { number; } \\
10 \mathrm{~mm} \\
\text { ball, } \\
3,000 \mathrm{~kg} \\
\text { load }\end{array}$ & $\begin{array}{c}\text { Maxi- } \\
\text { mum } \\
\text { variation } \\
\text { of Brinell } \\
\text { number }{ }^{1}\end{array}$ & Cast iron & $\begin{array}{c}\text { Average } \\
\text { Brinell } \\
\text { number; } \\
10 \mathrm{~mm} \\
\text { ball, } \\
3,000 \mathrm{~kg} \\
\text { load }\end{array}$ & $\begin{array}{c}\text { Maxi- } \\
\text { mum } \\
\text { variation } \\
\text { of Brinell } \\
\text { number } 1\end{array}$ \\
\hline $\begin{array}{l}\text { A } \\
\text { B- } \\
\text { C }- \\
\text { D. }\end{array}$ & , & $\begin{array}{l}156 \\
165 \\
192 \\
184\end{array}$ & $\begin{array}{r}\text { Per cent } \\
11.5 \\
7.3 \\
9.9 \\
10.3\end{array}$ & $\begin{array}{l}E \\
G \\
G \\
H\end{array}$ & $\begin{array}{l}184 \\
189 \\
165 \\
216\end{array}$ & $\begin{array}{r}\text { Per cent } \\
11.4 \\
15.3 \\
15.8 \\
17.5\end{array}$ \\
\hline
\end{tabular}

1 For 12 determinations. 
It will be noticed that there was a considerable difference between the Brinell numbers for these cast irons. The cast iron $\mathrm{A}$ was the softest and $\mathrm{H}$ the hardest of all. None of them, however, was too hard to be easily machined.

\section{TRANSVERSE TEST}

The results of tests on machined coupons, on unmachined coupons, and on the whole sections of pipes are given in Tables 6,7 , and 8 .

(a) Machined Coupons (see Fig. 1). - In order to compare the strengths of the specimens of different thicknesses, modulus of rupture was computed both for machined and unmachined specimens.

In order to make a direct comparison of deflections possible, values were computed for the average thickness of all the transverse specimens. In the formula for deflection of a simple beam, the thickness enters into the denominator in the third power. The test values of deflections were, therefore, multiplied by a factor $\frac{h^{3}}{h^{3}{ }_{0}}$ where $h$ is the thickness of an individual specimen, and $h_{0}$ the average thickness for all specimens. In order to illustrate the procedure let us consider the specimen A5 (Table 6). The deflection at rupture for this specimen was 0.080 inch; $h=0.425$ inch and the average thickness $h_{0}$ for all tested specimens was 0.382 inch.

Therefore, the deflection at rupture $\times \frac{h^{3}}{h^{3}{ }_{0}}$ is equal to $\frac{0.080 \times(0.425)^{3}}{(0.382)^{3}}$ $=0.110$ inch.

TABLE 6.-Transverse test of machined coupons

[All the specimens had a width $b=1.00$ inch and a span $l=5$ inches]

\begin{tabular}{|c|c|c|c|c|c|c|c|c|}
\hline Cast iron & $\begin{array}{c}\text { Specimen } \\
\text { number }\end{array}$ & $\begin{array}{l}\text { Thick- } \\
\text { ness } h\end{array}$ & $\underset{\text { Load at }}{\text { rupture } P}$ & $\begin{array}{l}\text { Modulus } \\
\text { of rupture } \\
S=\frac{3 P l}{2 b h^{2}}\end{array}$ & $\begin{array}{c}\text { Average } \\
\text { moodulus } \\
\text { of rup- } \\
\text { ture }\end{array}$ & $\begin{array}{l}\text { Deflec- } \\
\text { tion at } \\
\text { rupurture }\end{array}$ & $\begin{array}{c}\text { Deflec- } \\
\text { tion at } \\
\text { rupture } \\
\times \frac{h^{3}}{h^{3} o}\end{array}$ & $\begin{array}{c}\text { A verage } \\
\text { deflection } \\
\text { at rup- } \\
\text { ture } \times \frac{h^{3}}{h^{3}}\end{array}$ \\
\hline A.. & $\begin{array}{l}5 \\
6\end{array}$ & $\begin{array}{l}\text { Inch } \\
0.425 \\
\quad .444\end{array}$ & $\begin{array}{r}\text { Pounds } \\
1,047 \\
1,160\end{array}$ & $\begin{array}{r}\text { Lbs./in. } .^{2} \\
43,400 \\
41,200\end{array}$ & $\begin{array}{r}\text { Lbs./in. }{ }^{2} \\
43,800\end{array}$ & $\begin{array}{c}\text { Inch } \\
0.080 \\
.080\end{array}$ & $\begin{array}{l}\text { Inch } \\
0.110 \\
.125\end{array}$ & $\begin{array}{l}\text { Inch } \\
0.117\end{array}$ \\
\hline B.. & $\begin{array}{l}4 \\
5 \\
6\end{array}$ & $\begin{array}{l}.400 \\
.430 \\
.336\end{array}$ & $\begin{array}{l}925 \\
998 \\
569\end{array}$ & $\begin{array}{l}43,700 \\
40,400 \\
37,900\end{array}$ & 40,700 & $\begin{array}{l}.071 \\
.068 \\
.068\end{array}$ & $\begin{array}{l}.081 \\
.096 \\
.046\end{array}$ & .074 \\
\hline C... & $\begin{array}{l}4 \\
6\end{array}$ & $\begin{array}{r}.403 \\
.371\end{array}$ & $\begin{array}{l}917 \\
863\end{array}$ & $\begin{array}{l}42,300 \\
46,900\end{array}$ & 44,600 & $\begin{array}{l}.040 \\
.063\end{array}$ & $\begin{array}{l}.047 \\
.057\end{array}$ & .052 \\
\hline D. & $\begin{array}{l}4 \\
5\end{array}$ & $\begin{array}{l}.386 \\
.379\end{array}$ & $\begin{array}{l}903 \\
894\end{array}$ & $\begin{array}{l}45,400 \\
46,700\end{array}$ & 46,050 & $\begin{array}{l}.061 \\
.060\end{array}$ & $\begin{array}{l}.062 \\
.058\end{array}$ & .060 \\
\hline $\mathrm{E}_{\text {-. }}$ & $\begin{array}{l}4 \\
5 \\
6\end{array}$ & $\begin{array}{l}.399 \\
.364 \\
.407\end{array}$ & $\begin{array}{r}1,035 \\
828 \\
805\end{array}$ & $\begin{array}{r}48,700 \\
46,800 \\
136,500\end{array}$ & 44,000 & $\begin{array}{l}.066 \\
.064 \\
.039\end{array}$ & $\begin{array}{l}.075 \\
.055 \\
.047\end{array}$ & .059 \\
\hline$F_{\ldots}$ & $\begin{array}{l}4 \\
5 \\
6\end{array}$ & $\begin{array}{r}.410 \\
.320 \\
.373\end{array}$ & $\begin{array}{l}998 \\
594 \\
712\end{array}$ & $\begin{array}{l}41,300 \\
43,500 \\
38,400\end{array}$ & 41,100 & $\begin{array}{l}.054 \\
.079 \\
.052\end{array}$ & $\begin{array}{l}.066 \\
.046 \\
.048\end{array}$ & .053 \\
\hline $\mathrm{G}_{\text {. } .}$ & $\begin{array}{l}4 \\
5 \\
6\end{array}$ & $\begin{array}{l}.335 \\
.382 \\
.395\end{array}$ & $\begin{array}{l}520 \\
752 \\
869\end{array}$ & $\begin{array}{l}34,800 \\
38,600 \\
41,800\end{array}$ & 38,400 & $\begin{array}{l}.070 \\
.068 \\
.075\end{array}$ & $\begin{array}{l}.047 \\
.067 \\
.082\end{array}$ & .065 \\
\hline H.. & $\begin{array}{l}4 \\
5 \\
6\end{array}$ & $\begin{array}{l}.366 \\
.350 \\
.342\end{array}$ & $\begin{array}{l}880 \\
831 \\
730\end{array}$ & $\begin{array}{l}49,300 \\
50,900 \\
50,100\end{array}$ & 50,100 & $\begin{array}{l}.046 \\
.040 \\
.046\end{array}$ & $\begin{array}{l}.040 \\
.031 \\
.033\end{array}$ & .035 \\
\hline
\end{tabular}

1 Inclusions. 
(b) Unmachined Coupons.-A method similar to that described in paragraph $5(a)$ was used for the comparison of the deflections of unmachined coupons (see Table 7).

TABLE 7.-Transverse test of unmachined coupons

[All the specimens had a width $b=1$ inch and a span $l=10$ inches]

\begin{tabular}{|c|c|c|c|c|c|c|c|c|}
\hline Cast iron & $\begin{array}{l}\text { Speci- } \\
\text { men } \\
\text { No. }\end{array}$ & $\begin{array}{l}\text { Thick- } \\
\text { ness } h\end{array}$ & $\begin{array}{c}\text { Load at } \\
\text { rupture } \\
\qquad P\end{array}$ & $\begin{array}{c}\text { Modulus } \\
\text { of } \\
\text { rupture } \\
\mathrm{S}=\frac{3 P l}{2 b h^{2}}\end{array}$ & $\begin{array}{c}\text { Average } \\
\text { modulus } \\
\text { of } \\
\text { rupture }\end{array}$ & $\begin{array}{l}\text { Deflec- } \\
\text { tion at } \\
\text { rupture }\end{array}$ & $\begin{array}{l}\text { Deflec- } \\
\text { tion at } \\
\text { rupture } \\
\times \frac{h^{3}}{h^{3} \mathrm{o}}\end{array}$ & $\begin{array}{c}\text { Average } \\
\text { deflec- } \\
\text { tion at } \\
\text { rupture } \\
\times \frac{h^{3}}{h^{3} \text { o }}\end{array}$ \\
\hline A.- & $\begin{array}{l}1 \\
2 \\
3 \\
4\end{array}$ & $\begin{array}{r}\text { Inch } \\
0.425 \\
.377 \\
.416 \\
.403\end{array}$ & $\begin{array}{r}\text { Pounds } \\
470 \\
390 \\
455 \\
435\end{array}$ & $\begin{array}{c}L b s . / i n .^{2} \\
39,000 \\
41,150 \\
39,500 \\
40,150\end{array}$ & $\left\{\begin{array}{l}\text { Lbs./in. }{ }^{2} \\
40,000\end{array}\right.$ & $\begin{array}{r}\text { Inch } \\
0.247 \\
.308 \\
.262 \\
.280\end{array}$ & $\begin{array}{r}\text { Inch. } \\
0.286 \\
.249 \\
.284 \\
.276\end{array}$ & $\begin{array}{l}\text { Inch. } \\
\quad 0.274\end{array}$ \\
\hline B... & $\begin{array}{l}1 \\
2 \\
3 \\
4\end{array}$ & $\begin{array}{r}.412 \\
.406 \\
.384 \\
.435\end{array}$ & $\begin{array}{l}420 \\
430 \\
405 \\
520\end{array}$ & $\begin{array}{l}37,200 \\
39,100 \\
41,150 \\
41,200\end{array}$ & 39,650 & $\begin{array}{l}.187 \\
.235 \\
.246 \\
.226\end{array}$ & $\begin{array}{l}.197 \\
.237 \\
.210 \\
.281\end{array}$ & .231 \\
\hline C.. & $\begin{array}{l}1 \\
2 \\
3 \\
4\end{array}$ & $\begin{array}{l}.414 \\
.396 \\
.401 \\
.436\end{array}$ & $\begin{array}{l}500 \\
470 \\
470 \\
515\end{array}$ & $\begin{array}{l}43,800 \\
44,900 \\
43,800 \\
40,700\end{array}$ & 43,300 & $\begin{array}{l}.182 \\
.201 \\
.174 \\
.136\end{array}$ & $\begin{array}{l}.195 \\
.188 \\
.169 \\
.170\end{array}$ & .180 \\
\hline D.. & $\begin{array}{l}1 \\
2 \\
3 \\
4\end{array}$ & $\begin{array}{r}.442 \\
.438 \\
.411 \\
.397\end{array}$ & $\begin{array}{l}570 \\
525 \\
480 \\
445\end{array}$ & $\begin{array}{l}43,800 \\
41,100 \\
42,700 \\
42,300\end{array}$ & 42,500 & $\begin{array}{l}.184 \\
.160 \\
.174 \\
.189\end{array}$ & $\begin{array}{l}.239 \\
.203 \\
.182 \\
.178\end{array}$ & .200 \\
\hline $\mathrm{E}_{-}$ & $\begin{array}{l}1 \\
2 \\
3 \\
4\end{array}$ & $\begin{array}{l}.401 \\
.400 \\
.369 \\
.333\end{array}$ & $\begin{array}{l}475 \\
510 \\
400 \\
350\end{array}$ & $\begin{array}{l}44,300 \\
47,800 \\
44,100 \\
47,300\end{array}$ & 45,900 & $\begin{array}{l}.205 \\
.263 \\
.243 \\
.309\end{array}$ & $\begin{array}{l}.199 \\
.254 \\
.184 \\
.175\end{array}$ & .203 \\
\hline$F_{--}$ & $\begin{array}{l}1 \\
2 \\
3 \\
4\end{array}$ & $\begin{array}{r}.389 \\
.381 \\
.345 \\
.389\end{array}$ & $\begin{array}{l}405 \\
420 \\
320 \\
450\end{array}$ & $\begin{array}{l}40,200 \\
43,400 \\
40,300 \\
44,600\end{array}$ & 42,100 & $\begin{array}{l}.185 \\
.206 \\
.205 \\
.203\end{array}$ & $\begin{array}{l}.164 \\
.172 \\
.127 \\
.180\end{array}$ & .161 \\
\hline G. & $\begin{array}{l}1 \\
2 \\
3 \\
4\end{array}$ & $\begin{array}{l}.397 \\
.399 \\
.435 \\
.435\end{array}$ & $\begin{array}{l}410 \\
415 \\
485 \\
460\end{array}$ & $\begin{array}{l}39,000 \\
39,100 \\
38,500 \\
36,500\end{array}$ & 38,300 & $\begin{array}{l}.206 \\
.223 \\
.212 \\
.194\end{array}$ & $\begin{array}{l}.194 \\
.214 \\
.163 \\
.241\end{array}$ & .203 \\
\hline H. & $\begin{array}{l}1 \\
2 \\
3 \\
4\end{array}$ & $\begin{array}{l}.426 \\
.437 \\
.444 \\
.381\end{array}$ & $\begin{array}{l}510 \\
520 \\
520 \\
445\end{array}$ & $\begin{array}{l}42,200 \\
40,9 C 0 \\
39,600 \\
46,000\end{array}$ & 42,150 & $\begin{array}{l}.141 \\
.132 \\
.133 \\
.160\end{array}$ & $\begin{array}{l}.164 \\
.166 \\
.175 \\
.133\end{array}$ & .159 \\
\hline
\end{tabular}

The considerable differences between the machined and unmachined coupons may be explained by the presence of the chilled surface in the unmachined specimens.

(c) Transverse Test of Sections of Pipes.-Because of the lack of uniformity of the wall thickness no attempt was made to compute the maximum stress at failure.

Table 8 gives the values of load at failure. 
TABLE 8.-Transverse test of pipes

[Span $=24$ inches]

\begin{tabular}{|c|c|c|c|c|c|c|c|c|c|}
\hline [ Cast iron & $\begin{array}{c}\text { Speci- } \\
\text { men } \\
\text { No. }\end{array}$ & $\begin{array}{l}\text { Load at } \\
\text { first } \\
\text { audible } \\
\text { crack }\end{array}$ & $\begin{array}{l}\text { Load at } \\
\text { failure }\end{array}$ & $\begin{array}{l}\text { Average } \\
\text { load at } \\
\text { failure }\end{array}$ & Cast iron & $\begin{array}{c}\text { Speci- } \\
\text { men } \\
\text { No. }\end{array}$ & $\begin{array}{l}\text { Load at } \\
\text { first } \\
\text { audible } \\
\text { crack }\end{array}$ & $\begin{array}{l}\text { Load at } \\
\text { failure }\end{array}$ & $\begin{array}{l}\text { Average } \\
\text { load at } \\
\text { failure }\end{array}$ \\
\hline A.. & $\begin{array}{l}1 \\
2 \\
3 \\
4 \\
5 \\
6\end{array}$ & $\begin{array}{r}\text { Pounds } \\
31,690 \\
28,120 \\
31,860 \\
28,760 \\
34,390 \\
32,430\end{array}$ & $\begin{array}{r}\text { Pounds } \\
36,160 \\
28,120 \\
31,860 \\
33,830 \\
34,920 \\
33,350\end{array}$ & $\begin{array}{l}\text { Pounds } \\
\qquad 32,870\end{array}$ & E..... & $\begin{array}{l}1 \\
2 \\
3 \\
4 \\
5 \\
6\end{array}$ & $\begin{array}{r}\text { Pounds } \\
25,350 \\
36,030 \\
27,800 \\
31,380 \\
29,500 \\
26,570\end{array}$ & $\begin{array}{r}\text { Pounds } \\
29,670 \\
45,750 \\
27,800 \\
31,380 \\
39,340 \\
26,570\end{array}$ & Pounds \\
\hline B.... & $\begin{array}{l}1 \\
2 \\
3 \\
4 \\
5 \\
6\end{array}$ & $\begin{array}{r}33,950 \\
31,910 \\
32,080 \\
37,470 \\
\end{array}$ & $\begin{array}{l}33,950 \\
31,910 \\
32,080 \\
37,470 \\
39,000 \\
36,070\end{array}$ & 35,060 & $F_{-. .}$ & $\begin{array}{l}1 \\
2 \\
3 \\
4 \\
5 \\
6\end{array}$ & $\begin{array}{l}23,450 \\
31,760 \\
22,500 \\
23,270 \\
25,160 \\
25,000\end{array}$ & $\begin{array}{l}23,450 \\
32,520 \\
24,040 \\
31,500 \\
25,160 \\
25,000\end{array}$ & 26,950 \\
\hline O..... & $\begin{array}{l}1 \\
2 \\
3 \\
4 \\
5 \\
6\end{array}$ & $\begin{array}{l}36,060 \\
37,660 \\
26,740 \\
26,560 \\
28,520 \\
24,850\end{array}$ & $\begin{array}{l}36,060 \\
39,090 \\
32,700 \\
30,880 \\
28,520 \\
34,030\end{array}$ & 33,570 & G... & $\begin{array}{l}1 \\
2 \\
3 \\
4 \\
5 \\
6\end{array}$ & $\begin{array}{l}24,560 \\
26,410 \\
32,420 \\
21,870 \\
26,820 \\
26,840\end{array}$ & $\begin{array}{l}24,560 \\
26,410 \\
32,420 \\
30,060 \\
26,890 \\
28,080\end{array}$ & 28,100 \\
\hline D... & $\begin{array}{l}1 \\
2 \\
3 \\
4 \\
5 \\
6\end{array}$ & $\begin{array}{l}38,700 \\
40,000 \\
30,040 \\
30,150 \\
32,860 \\
31,820\end{array}$ & $\begin{array}{l}41,110 \\
40,370 \\
39,570 \\
37,900 \\
32,860 \\
31,820\end{array}$ & 37,270 & H... & $\begin{array}{l}1 \\
2 \\
3 \\
4 \\
5 \\
6\end{array}$ & $\begin{array}{r}35,690 \\
37,060 \\
24,270\end{array}$ & $\begin{array}{l}32,620 \\
35,820 \\
37,030 \\
24,600 \\
19,820 \\
30,050\end{array}$ & 30,000 \\
\hline
\end{tabular}

Because the length of these specimens was short compared to the diameter, most of them failed in one of two ways-crushing at the ends at the bottom, crushing in the middle at the top (see fig. 1, 4). Comparing the results for the transverse tests, we see that the differences between the strengths of different cast irons were not great. The deflection for cast iron $\mathrm{H}$, was, however, in all cases, the smallest and that for cast iron $\mathrm{A}$ the largest.

\section{RING TEST}

(a) Machined Rings.-The maximum theoretical stress at failure (corresponding to the modulus of rupture in a simple beam test) was computed by the formula:

where

$$
S_{\max }=\frac{6 P r}{\pi l t^{2}}
$$

$P$ is the maximum load,

$r$, radius of the neutral surface of the wall; $r=\frac{D_{\text {outs }}+d_{\text {ins }}}{4}$.

$l=$ width

$t=$ thickness of the wall.

A comparison of the deflections was made in a way similar to that used for transverse specimens. An approxmiate formula for de- 
flection of a ring (which, strictly speaking, as with a simple beam, can be applied only within the elastic deformation) is

$$
\Delta_{\mathrm{d}}=1.64 \frac{\mathrm{Pr}^{3}}{E l t^{3}}
$$

The test values of deflection were multiplied by $\frac{t^{3}}{t^{3}{ }_{0}}$; where $t_{\mathrm{o}}$ was the average thickness of wall for all the rings which were tested.

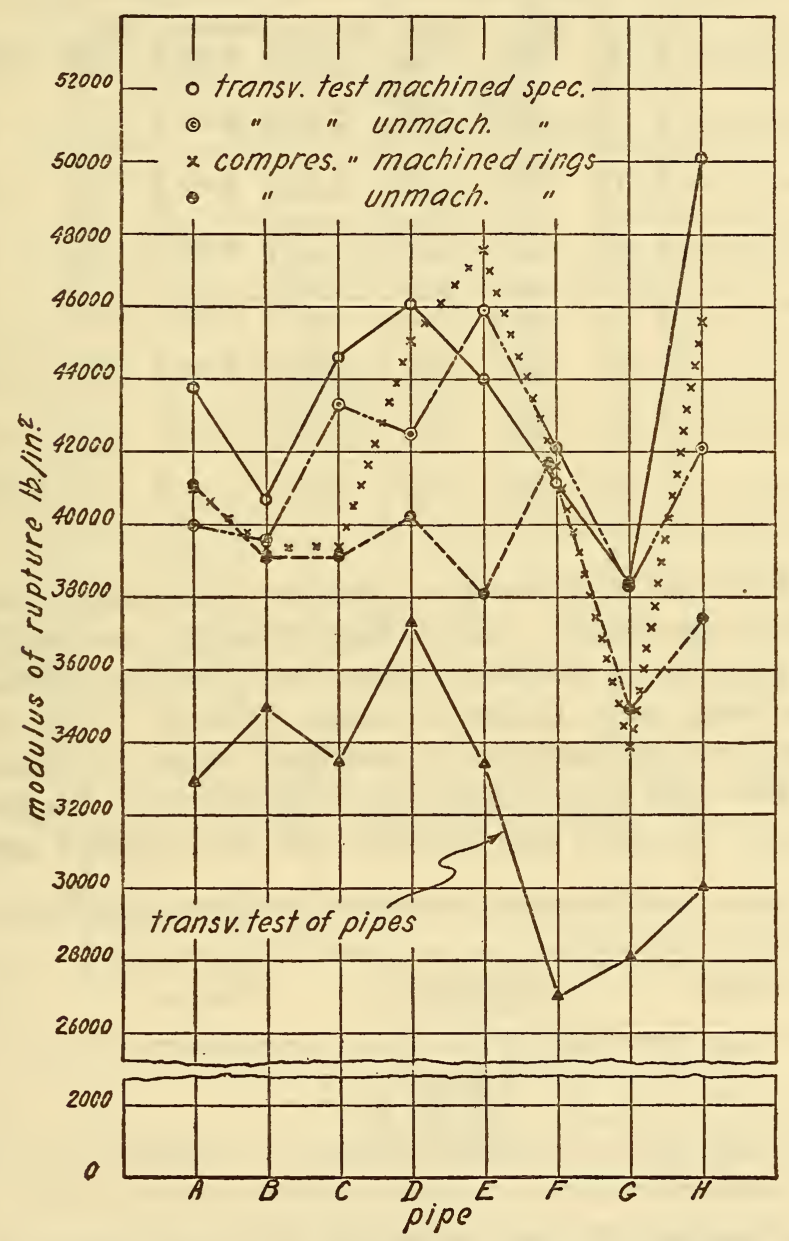

FIG. 4.-Moduli of rupture in transverse and compressive tests

Values for pipes (the lower curve) indicate the maximum loads

By this method the deflection of different rings was reduced to a common thickness.

No correction was made for differences in the radii of the rings, because these were nearly the same for all the rings. 
The results of compressive test of machined rings are given in Table 9.

TABLE 9.-Compressive test of machined rings

\begin{tabular}{|c|c|c|c|c|c|c|c|c|}
\hline Cast iron & $\begin{array}{l}\text { Ring } \\
\text { No. }\end{array}$ & $\begin{array}{l}\text { Thick- } \\
\text { ness of } \\
\text { wall }\end{array}$ & $\begin{array}{l}\text { Maxi- } \\
\text { mum } \\
\text { load }\end{array}$ & $\begin{array}{l}\text { Maxi- } \\
\text { mum the- } \\
\text { oretical } \\
\text { stress at } \\
\text { failure }\end{array}$ & $\begin{array}{l}\text { Average } \\
\text { maxi- } \\
\text { mum the- } \\
\text { oretical } \\
\text { stress }\end{array}$ & $\begin{array}{l}\text { Deflec- } \\
\text { tion at } \\
\text { failure }\end{array}$ & $\begin{array}{l}\text { Deflec- } \\
\text { tion at } \\
\text { failure } \\
\times_{t^{t^{3}} \mathrm{o}}\end{array}$ & $\begin{array}{c}\text { Average } \\
\text { deflec- } \\
\text { tion at } \\
\text { failure } \\
\times \frac{t^{3}}{t^{3} 0}\end{array}$ \\
\hline A.. & $\left\{\begin{array}{l}3 \\
4\end{array}\right.$ & $\begin{array}{l}\text { Inch } \\
0.325 \\
.312\end{array}$ & $\begin{array}{r}\text { Pounds } \\
2,090 \\
1,950\end{array}$ & $\begin{array}{r}\text { Lbs./in. }{ }^{2} \\
40,700 \\
41,400\end{array}$ & $\begin{array}{r}\text { Lbs./in. }{ }^{2} \\
41,050\end{array}$ & $\begin{array}{r}\text { Inch } \\
0.198 \\
.198\end{array}$ & $\begin{array}{r}0.218 \\
.192\end{array}$ & 0.205 \\
\hline B.. & $\begin{array}{l}4 \\
6\end{array}$ & $\begin{array}{l}.309 \\
.307\end{array}$ & $\begin{array}{l}1,880 \\
1,730\end{array}$ & $\begin{array}{l}40,800 \\
38,000\end{array}$ & 39,400 & $\begin{array}{l}.178 \\
.175\end{array}$ & $\begin{array}{l}.168 \\
.162\end{array}$ & .165 \\
\hline C.. & $\begin{array}{l}3 \\
4\end{array}$ & $\begin{array}{l}.312 \\
.344\end{array}$ & $\begin{array}{l}1,980 \\
2,070\end{array}$ & $\begin{array}{l}42,600 \\
36,300\end{array}$ & 39,450 & $\begin{array}{l}.148 \\
.144\end{array}$ & $\begin{array}{l}.144 \\
.187\end{array}$ & .166 \\
\hline D. & $\begin{array}{l}2 \\
5\end{array}$ & $\begin{array}{l}.342 \\
.346\end{array}$ & $\begin{array}{l}2,490 \\
2,680\end{array}$ & $\begin{array}{l}44,300 \\
45,900\end{array}$ & 45,100 & $\begin{array}{l}.156 \\
.150\end{array}$ & $\begin{array}{r}.199 \\
.198\end{array}$ & . 199 \\
\hline E.. & $\frac{1}{2}$ & $\begin{array}{l}.313 \\
.323\end{array}$ & $\begin{array}{l}2,250 \\
2,420\end{array}$ & $\begin{array}{l}47,300 \\
47,900\end{array}$ & 47,600 & $\begin{array}{l}.178 \\
.174\end{array}$ & $\begin{array}{l}.174 \\
.187\end{array}$ & .181 \\
\hline $\mathrm{F}_{-}$ & $\left\{\begin{array}{l}4 \\
6\end{array}\right.$ & $\begin{array}{r}310 \\
.291\end{array}$ & $\begin{array}{l}2,060 \\
1,610\end{array}$ & $\begin{array}{l}44,300 \\
39,000\end{array}$ & 41,650 & $\begin{array}{l}.170 \\
.155\end{array}$ & $\begin{array}{l}.161 \\
.122\end{array}$ & .142 \\
\hline G.. & $\left\{\begin{array}{l}3 \\
4\end{array}\right.$ & $\begin{array}{l}.300 \\
.307\end{array}$ & $\begin{array}{l}1,460 \\
1,560\end{array}$ & $\begin{array}{l}33,600 \\
34,300\end{array}$ & 33,950 & $\begin{array}{l}.141 \\
.144\end{array}$ & $\begin{array}{l}.121 \\
.133\end{array}$ & .127 \\
\hline H.. & $\left\{\begin{array}{l}3 \\
6\end{array}\right.$ & $\begin{array}{l}.300 \\
.306\end{array}$ & $\begin{array}{l}1,850 \\
2,230\end{array}$ & $\begin{array}{l}42,200 \\
49,100\end{array}$ & 45,650 & $\begin{array}{r}.110 \\
.116\end{array}$ & $\begin{array}{l}.095 \\
.106\end{array}$ & . 101 \\
\hline
\end{tabular}

As the deflection of transverse specimens was small it was difficult to measure it accurately. An attempt, however, was made to compute the modulus of elasticity using the deflection formula of the ring. The rings were loaded to about one-half of the maximum load, which corresponded to a maximum stress of about 20,000 lbs./in. ${ }^{2}$. For this first loading, the load-deflection diagram was a curved line. The load was removed and then applied again. For

$\mathrm{T}_{\mathrm{ABLE}}$ 10.-Modulus of elasticity obtained on machined rings

\begin{tabular}{|c|c|c|c|}
\hline Cast iron & $\begin{array}{l}\text { Modulus of } \\
\text { elasticity }\end{array}$ & Cast iron & $\begin{array}{l}\text { Modulus of } \\
\text { elasticity }\end{array}$ \\
\hline $\begin{array}{l}\mathrm{A} \\
\mathrm{B} \\
\mathrm{B} \\
\mathrm{C} \\
\mathrm{D}\end{array}$ & $\begin{array}{l}\text { Lbs./in. } \\
10,100,000 \\
9,750,000 \\
10,750,000 \\
12,000,000\end{array}$ & $\begin{array}{l}\mathrm{E} \\
\mathrm{F} \\
\mathrm{G} \\
\mathrm{H}\end{array}$ & $\begin{array}{l}\text { Lbs./in.2 } \\
10,900,000 \\
10,000,000 \\
9,300,000 \\
13,750,000\end{array}$ \\
\hline
\end{tabular}

the second loading, the load-deflection curve was nearly a straight line. Values of the modulus of elasticity were obtained from the results of this second loading. These values are given in Table 10 .

They are lower than the values for the modulus of cast iron which are usually obtained from tensile or compressive tests, and they can 
be only considered comparative. The results show that considerable differences exist between the moduli for different irons, the maximum for cast iron $\mathrm{H}$ and the minimum for $\mathrm{G}$.

(b) Unmachined Rings.-In addition to the strength of the unmachined rings, which is given in Table 11, the maximum theo-

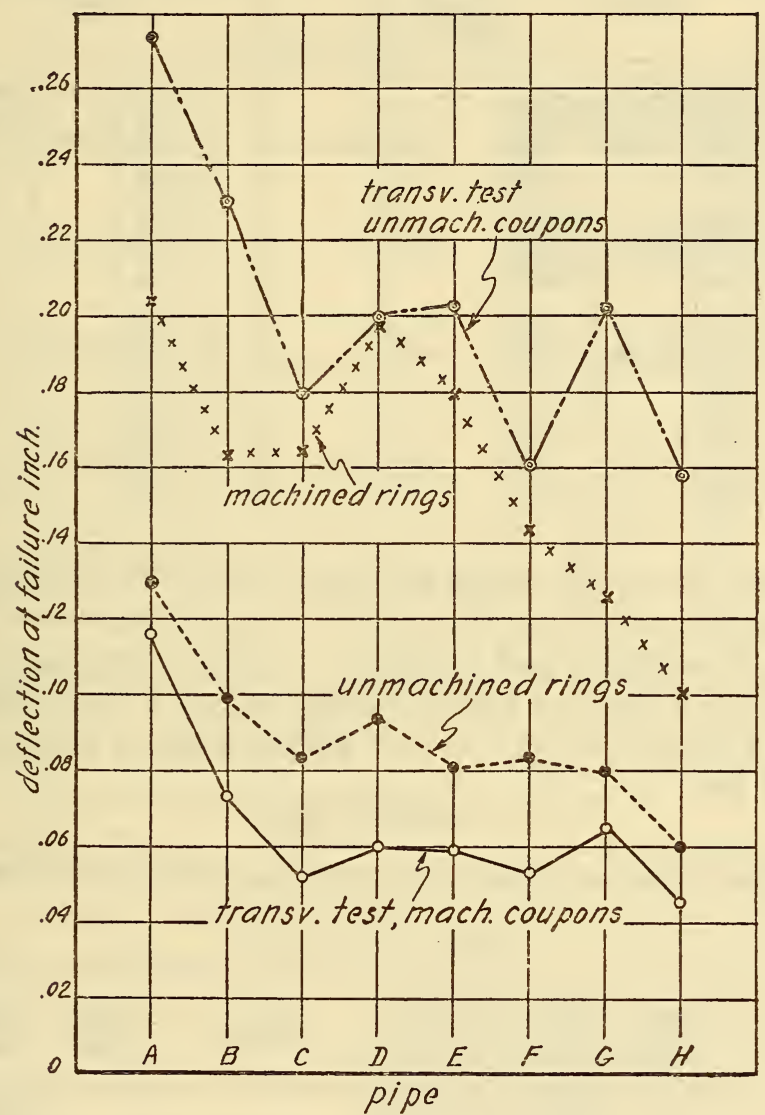

FIG. 5.-Deflections at failure in transverse and compressive tests

retical stress (modulus of rupture) was also computed using only average values for the maximum load, for the diameter, and for the thickness of the wall for all rings of a given cast iron.

The test values of deflections were also reduced to a common average thickness of wall as it was done for machined rings. 
$\mathrm{T}_{\mathrm{ABLE}}$ 11.-Compressive test of unmachined rings

\begin{tabular}{|c|c|c|c|c|c|c|c|c|c|c|c|}
\hline Cast iron & $\begin{array}{l}\text { Ring } \\
\text { No. }\end{array}$ & $\begin{array}{l}\text { Maxi- } \\
\text { mum } \\
\text { load }\end{array}$ & $\begin{array}{l}\text { Aver- } \\
\text { age } \\
\text { maxi- } \\
\text { mum } \\
\text { theo- } \\
\text { retical } \\
\text { stress }\end{array}$ & $\begin{array}{c}\text { Deflec- } \\
\text { tion } \\
\text { at } \\
\text { failure }\end{array}$ & $\begin{array}{l}\text { A verage } \\
\text { deflection } \\
\text { at failure } \\
\text { reduced } \\
\text { to the } \\
\text { average } \\
\text { thick- } \\
\text { ness } \\
\text { of wall }\end{array}$ & Cast iron & $\begin{array}{l}\text { Ring } \\
\text { No. }\end{array}$ & $\begin{array}{l}\text { Maxi- } \\
\text { mum } \\
\text { load }\end{array}$ & $\begin{array}{l}\text { Aver- } \\
\text { age } \\
\text { maxi- } \\
\text { mum } \\
\text { theo- } \\
\text { retical } \\
\text { stress }\end{array}$ & $\begin{array}{l}\text { Deflec- } \\
\text { tion } \\
\text { at } \\
\text { failure }\end{array}$ & $\begin{array}{l}\text { Average } \\
\text { deflection } \\
\text { at failure } \\
\text { reduced } \\
\text { to the } \\
\text { average } \\
\text { thick- } \\
\text { ness } \\
\text { of wall }\end{array}$ \\
\hline A.. & $\begin{array}{l}1 \\
2 \\
5 \\
6\end{array}$ & $\begin{array}{c}\text { Pounds } \\
3,310 \\
3,380 \\
3,900 \\
4,100\end{array}$ & $\left\{\begin{array}{l}\text { Lbs./in. }{ }^{2} \\
41,100\end{array}\right.$ & $\left\{\begin{array}{l}\text { Inch } \\
0.109 \\
.126 \\
.128 \\
.128\end{array}\right.$ & $\begin{array}{l}\text { Inch } \\
\quad 0.130\end{array}$ & E... & $\begin{array}{l}3 \\
4 \\
5 \\
6\end{array}$ & $\begin{array}{c}\text { Pounds } \\
3,320 \\
1,990 \\
3,690 \\
3,520\end{array}$ & $\begin{array}{l}\text { Lbs./in. }{ }^{2} \\
38,100\end{array}$ & $\begin{array}{l}\text { Inch } \\
0.102 \\
.056 \\
.098 \\
.099\end{array}$ & $\begin{array}{l}\text { Inch } \\
\qquad 0.081\end{array}$ \\
\hline B... & $\begin{array}{l}1 \\
2 \\
3 \\
5\end{array}$ & $\begin{array}{l}3,660 \\
3,540 \\
3,720 \\
3,920\end{array}$ & 39,100 & $\begin{array}{l}.099 \\
.078 \\
.096 \\
.095\end{array}$ & .099 & $F_{-}$ & $\begin{array}{l}1 \\
2 \\
3 \\
5\end{array}$ & $\begin{array}{l}3,680 \\
3,570 \\
3,170 \\
3,760\end{array}$ & 41,700 & $\begin{array}{l}.084 \\
.086 \\
.076 \\
.098\end{array}$ & .083 \\
\hline C & $\begin{array}{l}1 \\
2 \\
5 \\
6\end{array}$ & $\begin{array}{l}3,440 \\
3,750 \\
3,530 \\
3,230\end{array}$ & 39,100 & $\begin{array}{l}.080 \\
.084 \\
.079 \\
.092\end{array}$ & .083 & $G_{\ldots}$ & $\begin{array}{l}1 \\
2 \\
5 \\
6\end{array}$ & $\begin{array}{l}2,580 \\
2,960 \\
3,130 \\
3,430\end{array}$ & 34,800 & $\begin{array}{l}.068 \\
.080 \\
.084 \\
.117\end{array}$ & .080 \\
\hline D.. & $\begin{array}{l}1 \\
3 \\
4 \\
6\end{array}$ & $\begin{array}{l}3,470 \\
4,080 \\
4,260 \\
4,270\end{array}$ & 40,200 & $\begin{array}{l}.062 \\
.088 \\
.081 \\
.082\end{array}$ & .094 & H... & $\begin{array}{l}1 \\
2 \\
4 \\
5\end{array}$ & $\begin{array}{l}3,880 \\
3,380 \\
3,250 \\
2,580\end{array}$ & 37,400 & $\begin{array}{l}.057 \\
.050 \\
.071 \\
.060\end{array}$ & .060 \\
\hline
\end{tabular}

Examining the results of ring and transverse tests (see figs. 4 and 5), we see that they are fairly comparable among themselves, both with respect to the strength and deflection. It is evident, however, that a ring cut out of pipe is a better representative of the material of the pipe than a coupon cut out of the wall of pipe, or than a so-called arbitration bar.

\section{SHEAR TEST}

The values for mean shearing stresses are given in Table 12 .

TABLe 12.-Shear test

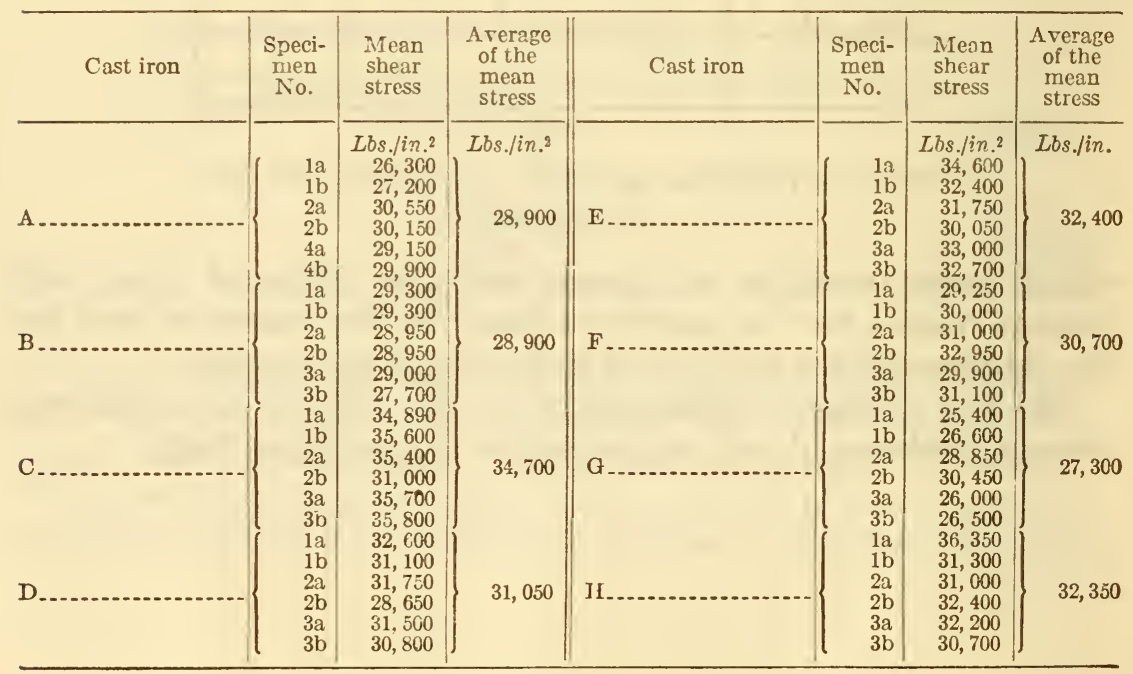




\section{IMPACT TEST}

The energy absorbed by the impact specimens (see Table 13) was small for both notched and unnotched specimens. It is evident, however, that cast iron $\mathrm{H}$ had somewhat lower impact resistance than the other cast irons.

TABLE 13.-Impact test

\begin{tabular}{|c|c|c|c|c|}
\hline \multirow{2}{*}{ Cast iron } & \multicolumn{2}{|c|}{$\begin{array}{l}\text { Izod impact ma- } \\
\text { chine capacity } 120 \\
\text { ft.-lb. }\end{array}$} & \multicolumn{2}{|c|}{$\begin{array}{c}\text { Charpy impact } \\
\text { machine capacity } \\
8 \mathrm{ft} .-\mathrm{lb} .\end{array}$} \\
\hline & $\begin{array}{l}\text { Un- } \\
\text { notched } \\
\text { speci- } \\
\text { mens }\end{array}$ & $\begin{array}{l}\text { Notched } \\
\text { speci- } \\
\text { mens }\end{array}$ & $\begin{array}{l}\text { Un- } \\
\text { notched } \\
\text { speci- } \\
\text { mens }\end{array}$ & $\begin{array}{l}\text { Notched } \\
\text { speci- } \\
\text { mens }\end{array}$ \\
\hline $\begin{array}{l}\mathrm{A} \\
\mathrm{A} \\
\mathrm{B}\end{array}$ & $\begin{array}{r}\text { Ft. }-l b . \\
\text { 1. } 50 \\
\text { 1. } 45 \\
\text { 1. } 35 \\
\text { 1. } 40\end{array}$ & $\begin{array}{r}F t .-l b . \\
0.75 \\
.60 \\
.50 \\
.60\end{array}$ & $\begin{array}{r}F t .-l b . \\
1.74 \\
1.42 \\
1.40 \\
1.50\end{array}$ & $\begin{array}{r}F t .-l b . \\
1.04 \\
.90 \\
.76 \\
.85\end{array}$ \\
\hline $\begin{array}{l}\mathrm{E} \\
\mathrm{H} \\
\mathrm{A} \text { verage for A to } \mathrm{G} \text { (American pipe) } \\
\text { Ratio of impact } \text { values for } \mathrm{H} \text { pipe to the average for A merican }\end{array}$ & $\begin{array}{l}1.75 \\
1.70 \\
\text { 1. } 55 \\
\text { 1. } 35 \\
1.53\end{array}$ & $\begin{array}{l}.65 \\
.55 \\
.50 \\
.30 \\
.59\end{array}$ & $\begin{array}{l}1.55 \\
1.58 \\
1.47 \\
1.08 \\
1.54\end{array}$ & $\begin{array}{l}.88 \\
.77 \\
.84 \\
.51 \\
.86\end{array}$ \\
\hline pipe (A to G) & 88.2 & 50.8 & 70.6 & 59.3 \\
\hline
\end{tabular}

In considering the impact resistance, the greater reliance should be placed on the results obtained in the Charpy impact machine, because it has a lower capacity and the impact values could be obtained in this machine with a greater accuracy.

It is possible that the values for the unnotched specimens represent more nearly the relative resistance offered by these samples to impact in service, because the pipe is used in the unnotched condition.

The impact resistance of the $\mathrm{H}$ cast iron is about three-fourths the average of all other specimens. It is impossible to determine from these tests whether or not this lower impact resistance would cause failure of the $\mathrm{H}$ pipe in service under conditions for which the other pipes would be saitsfactory. Apparently, the $\mathrm{H}$ pipe must be handled somewhat more carefully than the other pipe to avoid damage to the pipe. When the pipe is in place in the ground, the cushioning effect of the earth would in all probability reduce the impact stresses to such an extent that the pipe would fail only when the static load exceeded its strength. It is evident that in the case of nonuniform settlement of the ground, of two pipes having the same strength but unequal deflection, the pipe which has a greater deflection would be safer.

\section{HYDROSTATIC TEST}

The results of the hydrostatic test are given in Table 14. The average values of the bursting pressure for all the specimens was 
greater than five times the specification value (300 lbs./in. $\left.{ }^{2}\right)$ and in no case did bursting occur at pressures lower than $700 \mathrm{lbs} . / \mathrm{in} .^{2}$.

TABLE 14.-Hydrostatic test

\begin{tabular}{|c|c|c|c|c|c|}
\hline $\begin{array}{l}\text { Cast } \\
\text { iron }\end{array}$ & $\begin{array}{l}\text { Speci- } \\
\text { men } \\
\text { No. }\end{array}$ & Method of applying pressure & $\begin{array}{l}\text { Type of } \\
\text { fracture } 1\end{array}$ & $\begin{array}{l}\text { Pressure } \\
\text { at failure }\end{array}$ & $\begin{array}{l}\text { Average } \\
\text { pressure } \\
\text { at failure }\end{array}$ \\
\hline .... & $\begin{array}{l}1 \\
2 \\
3 \\
5 \\
4 \\
6\end{array}$ & 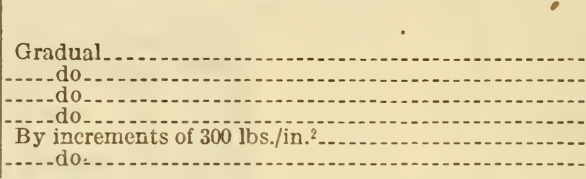 & $\begin{array}{l}\text { I } \\
\text { I } \\
\text { I } \\
\text { O } \\
\text { I } \\
\text { I }\end{array}$ & $\begin{array}{r}\text { Lbs./in.2 } \\
2,200 \\
2,390 \\
2,230 \\
2,280 \\
1,980 \\
2,080\end{array}$ & $\begin{array}{r}\text { Lbs./in. }{ }^{2} \\
2,290\end{array}$ \\
\hline .. & $\begin{array}{l}2 \\
3 \\
5 \\
6 \\
1 \\
4\end{array}$ & Gradual & $\begin{array}{l}\mathrm{O} \\
\mathrm{I} \\
\mathrm{Y} \\
\mathrm{X} \\
\mathrm{X} \\
\mathrm{I}\end{array}$ & $\begin{array}{l}2,400 \\
2,290 \\
1,720 \\
2,340 \\
2,400 \\
2,520\end{array}$ & 2,460 \\
\hline 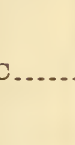 & $\begin{array}{l}1 \\
2 \\
4 \\
5 \\
3 \\
6\end{array}$ & $\begin{array}{c}\text { Gradual } \\
\text { By increments } \\
\text { indo }\end{array}$ & $\begin{array}{l}\mathrm{I} \\
\mathrm{Y} \\
\mathrm{I} \\
\mathrm{X} \\
\mathrm{Y} \\
\mathrm{Y}\end{array}$ & $\begin{array}{l}2,210 \\
1,700 \\
700 \\
1,790 \\
1,800 \\
1,340\end{array}$ & $\begin{array}{c}1,600 \\
1,570\end{array}$ \\
\hline D ... & $\begin{array}{l}2 \\
3 \\
4 \\
5 \\
1 \\
6\end{array}$ & $\begin{array}{l}\text { Gradual } \\
\text { By increments. }\end{array}$ & $\begin{array}{l}\text { I } \\
\text { I } \\
\text { O } \\
\text { O } \\
\text { O } \\
\text { I }\end{array}$ & $\begin{array}{l}2,640 \\
2,320 \\
2,510 \\
2,450 \\
2,620 \\
1,990\end{array}$ & 2,300 \\
\hline E. & $\begin{array}{l}1 \\
2 \\
3 \\
4 \\
5 \\
6\end{array}$ & \begin{tabular}{l} 
Gradual \\
\hdashline By increments \\
\hdashline do \\
\hdashline do
\end{tabular} & $\begin{array}{l}\mathrm{X} \\
\mathrm{O} \\
\mathrm{I} \\
\mathrm{I} \\
\mathrm{Y} \\
\mathrm{I}\end{array}$ & $\begin{array}{l}2,670 \\
2,560 \\
2,220 \\
1,210 \\
2,100 \\
2,010\end{array}$ & 2,055 \\
\hline F & $\begin{array}{l}1 \\
2 \\
4 \\
5 \\
3 \\
6\end{array}$ & $\begin{array}{l}\text { Gradual } \\
\text { By increments. }\end{array}$ & $\begin{array}{l}\mathrm{I} \\
\mathrm{X} \\
\mathrm{X} \\
\mathrm{I} \\
\mathrm{Y} \\
\mathrm{Y}\end{array}$ & $\begin{array}{l}1,650 \\
2,570 \\
2,320 \\
1,790 \\
1,500 \\
1,700\end{array}$ & 1,600 \\
\hline G.... & $\begin{array}{l}1 \\
4 \\
5 \\
6 \\
2 \\
3\end{array}$ & Gradual & $\begin{array}{l}\mathrm{Y} \\
\mathrm{I} \\
\mathrm{I} \\
\mathrm{I} \\
\mathrm{I} \\
\mathrm{I}\end{array}$ & $\begin{array}{l}1,690 \\
2,210 \\
1,790 \\
2,080 \\
1,580 \\
2,100\end{array}$ & 1,940 \\
\hline & $\begin{array}{l}2 \\
4 \\
5 \\
1 \\
3 \\
6\end{array}$ & Gradual & $\begin{array}{l}\mathrm{X} \\
\mathrm{X} \\
\mathrm{X} \\
\mathrm{X} \\
\mathrm{X} \\
\mathrm{I}\end{array}$ & $\begin{array}{l}2,520 \\
2,040 \\
2,820 \\
2,280 \\
2,080 \\
750\end{array}$ & 2,460 \\
\hline
\end{tabular}

1 I specimen broke longitudinally; $O$, specimen broke on a circumferential line in the threads; $Y$, specimen broke longitudinally in two diverging lines; $\mathrm{X}$, specimen was more or less shattered.

With the single exception of pipe B, all other pipes showed greater strength when pressure was applied uninterruptedly than when it was applied by increments. The pressures which caused failure were, however, so different for the specimens cut from the same pipe that it is not believed that the differences between the results of the gradual and increment loading are significant. 


\section{CONCLUSIONS}

(1) The differences in the strengths of these cast irons were not great. The strength of cast iron $H$ lay within the range of variation of the irons $\mathrm{A}$ to $\mathrm{G}$.

(2) There was a decided difference in the deflection, cast iron $\mathrm{H}$ having a smaller deflection than any other. This is shown in Table 15.

(3) The greater brittleness of cast iron $\mathrm{H}$ is evident from the suddenness of failure in the ring and transverse tests. The low deflection and brittleness was probably due to the higher content of phosphorus in cast iron $\mathrm{H}$ ( 1.85 per cent) than in the other cast irons (average 0.64 per cent).

(4) It is probable that the $\mathrm{H}$ pipe should be handled more carefully than the other pipes to avoid damage to the pipe. However, when in the ground, the static strength of the pipe is of greater importance than the resistance to impact.

(5) Comparatively few defects were found in any of the cast irons. All the pipes were sound and complied with the existing specifications for the hydrostatic test.

(6) The compressive test of the short sections of pipe gave the results which it is believed are as satisfactory a measure of the properties of the pipe as the transverse tests.

(7) Short sections of pipe more closely represent the material than the arbitration bars or coupons and the compressive test of the rings cut from the pipe is, therefore, suggested instead of transverse test.

TABLE 15.-Average strengths and defiections of cast irons $A$ to $G$ compared with those of cast iron $H$

\begin{tabular}{|c|c|c|c|c|c|c|}
\hline \multirow[b]{2}{*}{ Test } & \multicolumn{3}{|c|}{ Strength } & \multicolumn{3}{|c|}{ Deflection } \\
\hline & $\begin{array}{l}\text { Average } \\
\text { for cast } \\
\text { irons } A \\
\text { to } G\end{array}$ & $\underset{\mathrm{H}}{\text { Cast iron }}$ & $\begin{array}{c}\text { Differ- } \\
\text { ence be- } \\
\text { tween H } \\
\text { and the } \\
\text { average } \\
\text { for A to } \\
G\end{array}$ & $\begin{array}{l}\text { Average } \\
\text { for cast } \\
\text { irons } \mathrm{A} \\
\text { to } \mathrm{G}\end{array}$ & $\underset{\mathrm{H}}{\text { Cast iron }}$ & $\begin{array}{c}\text { Differ- } \\
\text { ence be- } \\
\text { tween H } \\
\text { and the } \\
\text { average } \\
\text { for A to } \\
G\end{array}$ \\
\hline 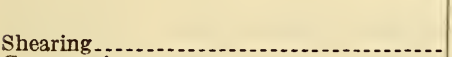 & $\begin{array}{c}\text { Lbs./in. }{ }^{2} \\
30,600\end{array}$ & $\begin{array}{c}\text { Lbs./in. }{ }^{2} \\
32,350\end{array}$ & $\begin{array}{r}\text { Per cent } \\
+5.7\end{array}$ & Inch & Inch & Per cent \\
\hline $\begin{array}{l}\text { Compressive: } \\
\text { (a) Machined rings. } \\
\text { (b) Unmachined rings. }\end{array}$ & $\begin{array}{r}42,000 \\
114,050\end{array}$ & $\begin{array}{r}46,750 \\
13,380\end{array}$ & $\begin{array}{r}+11.3 \\
-4.8\end{array}$ & $\begin{array}{r}0.170 \\
.093\end{array}$ & $\begin{array}{r}0.101 \\
.060\end{array}$ & $\begin{array}{l}-40.6 \\
-35.5\end{array}$ \\
\hline $\begin{array}{l}\text { Transverse: } \\
\text { (a) Machined coupons. } \\
\text { (b) Unmachined coupons } \\
\text { (c) Pipes... }\end{array}$ & $\begin{array}{r}42,660 \\
41,700 \\
232,500\end{array}$ & $\begin{array}{r}50,100 \\
42,150 \\
230,000\end{array}$ & $\begin{array}{r}+17.4 \\
+1.1 \\
-7.7\end{array}$ & .069 & $\begin{array}{l}.035 \\
.159\end{array}$ & $\begin{array}{r}-49.3 \\
-23.2 \\
-. . .-\end{array}$ \\
\hline
\end{tabular}




\section{DISCUSSION OF METHODS OF TESTING CAST-IRON PIPE}

When testing cast-iron pipe two principal questions are to be considered: (1) The effectiveness of the test in revealing the properties of pipe which are of importance in the service conditions, and (2) the cost of making the test.

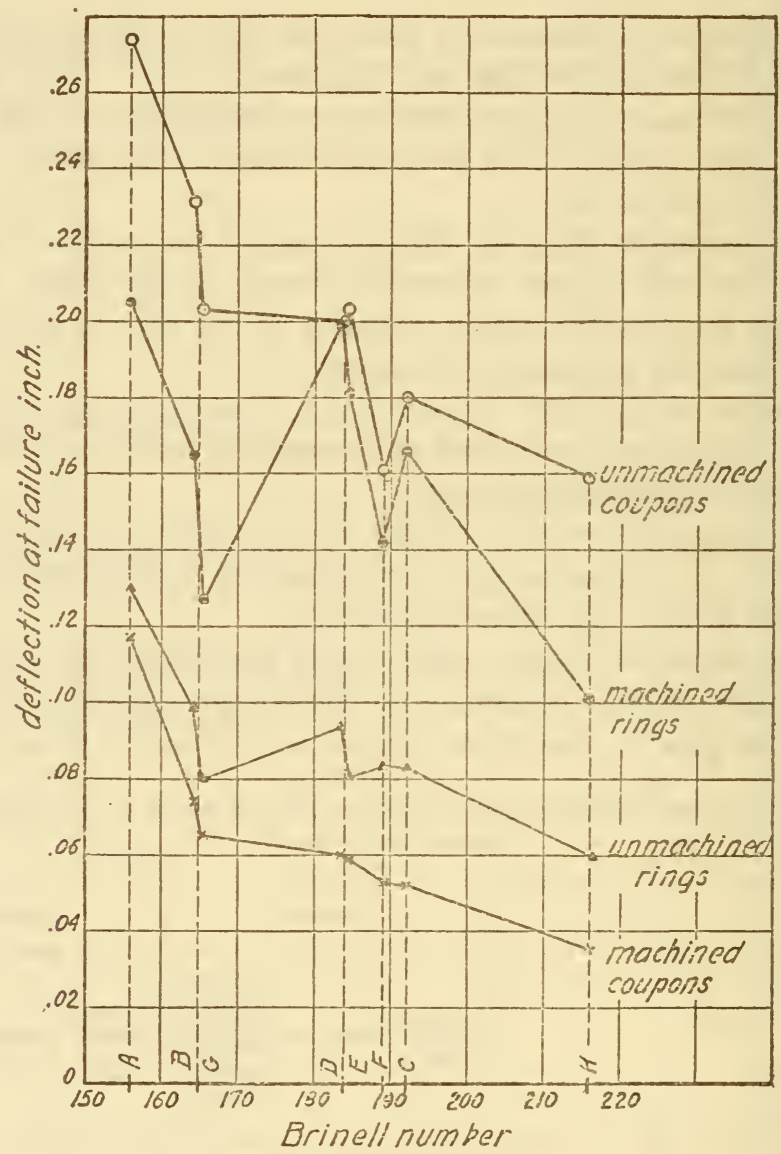

Fig. 6.-Relationship between the Brinell numbers and the deflections at failure

The letters represent the cast irons

These two considerations are liable to be conflicting and the problem which lies before the testing engineer is to choose proper tests and to make them in the least expensive way. Several unusual methods were used in this investigation to determine whether or not they have advantages over the usual methods. Examination of the test data shows wide variations in the results which is to be expected of cast iron. 


\section{BRINELL TEST}

The relation between the Brinell number and the other properties was considered because the Brinell test is inexpensive and can be made with usual laboratory equipment and does not require a highly trained personnel.

In general, no consistent relation can be found between the Brinell number and the strength. It was found (see fig. 6) that the Brinell number increases as the deflection of transverse or of ring specimens

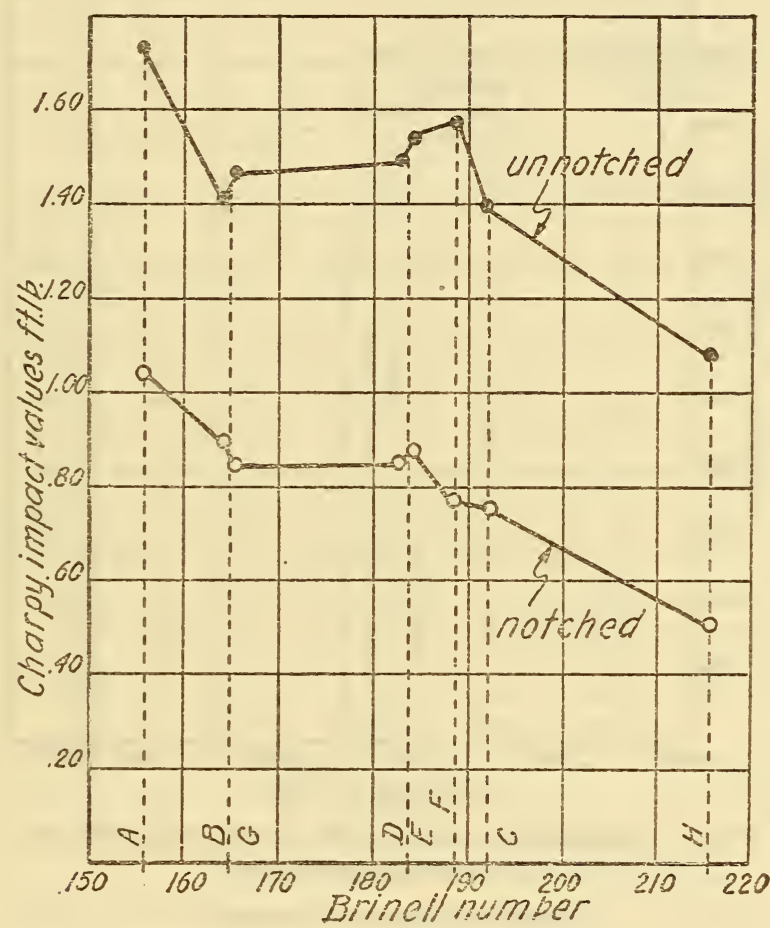

FIG. 7.-Rclationship between the Brinell numbers and the Charpy impact values

The letters represent the cast irons

decreases. If this is confirmed by further tests on commercial cast-iron pipe, the Brinell test could be used instead of determining deflection in transverse or ring test. However, it is unwise to use an indirect method to measure a property which can be measured directiy unless the former method offers some decided advantages.

The Brinell test could probably be used to determine whether or not the cast iron could be machined, but should not be required in purchase specifications unless it is found that it is impracticable to drill and tap commercial cast-iron pipe for connections. Comparing the Brinell numbers with the impact values (see fig. 7 ) it is found 
that, in general, the higher the Brinell number the lower the impact value. However, it does not seem probable that this relationship can be used in writing specifications.

\section{FLEXURE TESTS}

These included transverse tests of machined and unmachined coupons and the tests of machined and unmachined rings. Because the machining of specimens all over for the transverse or for the ring test

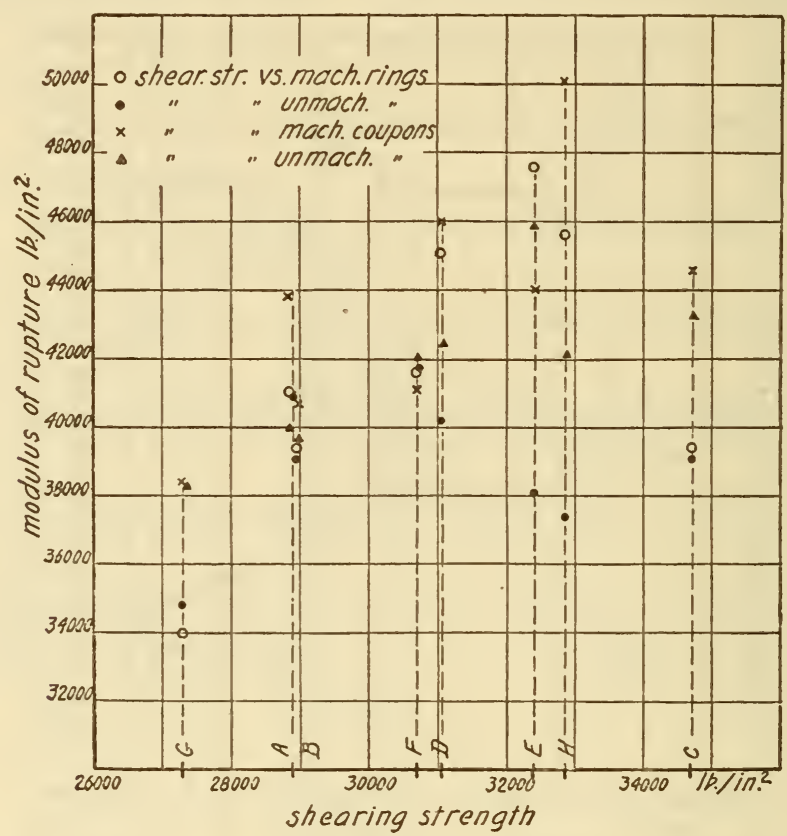

FIG. 8.-Relationship between the shearing strengths and the moduli of rupture

The letters represent the cast irons

is expensive the results of machined and unmachined specimens were compared. (See figs. 4 and 5.) It is evident that unmachined specimens can serve the purposes of comparison about as well as the machined specimens. The pipe is not machined before it is used. For this reason and also in order to reduce the cost of test, the specimens should not be machined except where this is necessary.

The results of transverse tests of pipes were as consistent with the results of transverse tests of coupons or with the results of ring tests as could be expected for cast iron and, therefore, it does not seem desirable to require transverse tests on the pipes, as no information is obtained which can not be obtained from the coupons or the rings. 


\section{SHEAR TEST}

To make the shear test satisfactorily requires special fixtures which are not usually available in testing laboratories. The relationship between the shearing strength and the modulus of rupture is not very definite. (See fig. 8.) Shearing strength probably increases with the

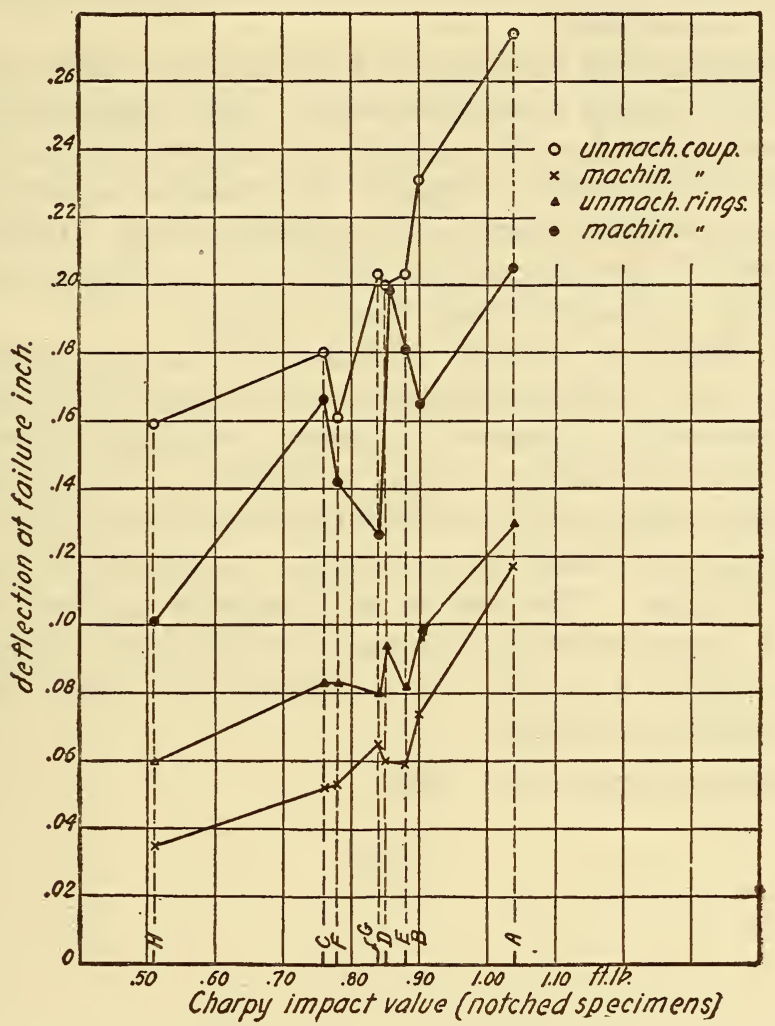

Fig. 9.-Relationship between the deflections at failure and the Charpy impact values

The letters represent the cast irons

increase of the modulus of rupture, and if the modulus is satisfactory the pipe will not fail under the shearing stresses incurred in practice.

\section{IMPACT TEST}

Figure 9 shows that the impact resistance increases if the deflection increases. It is therefore reasonable to measure the deflection in order to insure a satisfactory resistance to impact.

\section{HYDROSTATIC TEST}

The hydrostatic test is expensive and the results varied widely. Failure was in many cases due to the conditions at the end of the pipe 
where the caps were screwed onto the pipe. It is difficult to make these conditions uniform for all specimens. Therefore, this test does not appear suitable as an acceptance test of cast-iron pipe.

To summarize, it seems advisable in preparing specifications for cast-iron pipe-

(1) To consider the Brinell test only to detect pipe which it is impracticable to machine.

(2) To require tests on rings cut from the pipe which shall have a specified deflection for a specified load. These rings should preferably not be machined on the cylindrical surfaces either outside or inside. These rings would represent the material in the pipe more closely than arbitration bars cast in separate molds. The rings give, it is believed, all the information which can be obtained from transverse coupons cut longitudinally from the pipe.

(3) The deflection of rings or transverse coupons appears from these tests to be a satisfactory comparative measure of impact resistance. If, however, a measure of impact resistance which is independent of the dimensions of pipe, is desired, or if it is found that cast-iron pipe which has satisfactory defiection either in the ring test or in the transverse test, has low impact resistance, an impact test should be required. This test is not expensive and can be quickly made upon apparatus which is usually available in a testing laboratory. An impact machine of low capacity is highly desirable if accurate results are desired.

Washington, October 11, 1926. 